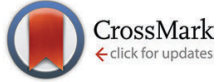

Cite this: Phys. Chem. Chem. Phys., 2016, 18, 30662

Received 22nd September 2016, Accepted 19th October 2016

DOI: $10.1039 / c 6 c p 06513 a$

www.rsc.org/pccp

\section{Development of type-I/type-II hybrid dye sensitizer with both pyridyl group and catechol unit as anchoring group for type-I/type-II dye-sensitized solar cell $\dagger$}

\author{
Yousuke Ooyama, ${ }^{*}$ Kensuke Furue, Toshiaki Enoki, Masahiro Kanda, Yohei Adachi \\ and Joji Ohshita*
}

\begin{abstract}
A type-l/type-II hybrid dye sensitizer with a pyridyl group and a catechol unit as the anchoring group has been developed and its photovoltaic performance in dye-sensitized solar cells (DSSCs) is investigated. The sensitizer has the ability to adsorb on $\mathrm{TiO}_{2}$ electrode through both the coordination bond at Lewis acid sites and the bidentate binuclear bridging linkage at Brønsted acid sites on the $\mathrm{TiO}_{2}$ surface, which makes it possible to inject an electron into the conduction band of the $\mathrm{TiO}_{2}$ electrode by the intramolecular charge-transfer (ICT) excitation (type-I pathway) and by the photoexcitation of the dyeto- $\mathrm{TiO}_{2}$ charge transfer (DTCT) band (type-II pathway). It was found that the type-l/type-II hybrid dye sensitizer adsorbed on $\mathrm{TiO}_{2}$ film exhibits a broad photoabsorption band originating from ICT and DTCT characteristics. Here we reveal the photophysical and electrochemical properties of the type-I/type-II hybrid dye sensitizer bearing a pyridyl group and a catechol unit, along with its adsorption modes onto $\mathrm{TiO}_{2}$ film, and its photovoltaic performance in type-l/type-II DSSC, based on optical (photoabsorption and fluorescence spectroscopy) and electrochemical measurements (cyclic voltammetry), density functional theory (DFT) calculation, FT-IR spectroscopy of the dyes adsorbed on $\mathrm{TiO}_{2}$ film, photocurrent-voltage $(I-V)$ curves, incident photon-to-current conversion efficiency (IPCE) spectra, and electrochemical impedance spectroscopy (EIS) for DSSC.
\end{abstract}

\section{Introduction}

Since Grätzel and co-workers produced high-performance dye-sensitized solar cells (DSSCs) employing a Ru-complex dye-adsorbed $\mathrm{TiO}_{2}$ electrode in 1991, which showed a solar energy-to-electricity conversion yield $(\eta)$ of $11 \%,{ }^{1}$ DSSCs have received considerable attention as one of the most promising new renewable photovoltaic cells alternative to conventional solar cells based on silicon because they have interesting construction and operational principles, and a colorful and decorative nature. ${ }^{2-8}$ To further improve the photovoltaic performance based on the construction and operational principles of DSSC, much effort has been made towards the development of various types of organic dye sensitizers that possess the following characteristics: (i) good light-harvesting features over the wide spectral region of sunlight, (ii) high electron-injection efficiencies from photoexcited dyes to the conduction band (CB) of the

Department of Applied Chemistry, Graduate School of Engineering,

Hiroshima University, Higashi-Hiroshima 739-8527, Japan.

E-mail: yooyama@hiroshima-u.ac.jp; Fax: +81 82-424-5494

$\dagger$ Electronic supplementary information (ESI) available. See DOI: 10.1039/c6cp06513a
$\mathrm{TiO}_{2}$ electrode, (iii) high dye loading and high surface coverage of the $\mathrm{TiO}_{2}$ electrode, (iv) efficient re-reduction of the oxidized dyes by electron transfer from $\mathrm{I}^{-}$ions in the electrolyte containing the $\mathrm{I}_{3}^{-} / \mathrm{I}^{-}$redox couple, (v) reduction of charge recombination between the injected electrons in the $\mathrm{CB}$ of the $\mathrm{TiO}_{2}$ electrode and the oxidized dyes or $\mathrm{I}_{3}{ }^{-}$ions in the electrolyte, and (vi) reduction of dye aggregation on the $\mathrm{TiO}_{2}$ surface.,

$\mathrm{TiO}_{2}$-based DSSCs can be classified into two types, I and II, depending on the electron-injection pathway from the dye to the $\mathrm{CB}$ of the $\mathrm{TiO}_{2}$ electrode (Fig. 1 ). ${ }^{4}$ The pathway for type-I DSSCs is photoexcitation of the local band of the dye adsorbed on the $\mathrm{TiO}_{2}$ surface followed by an electron injection from the photoexcited dye to the $\mathrm{CB}$ of the $\mathrm{TiO}_{2}$ electrode (Fig. 1a: i.e., an electron is excited from the HOMO to the LUMO level of the dye by sunlight illumination, followed by injection into the $\mathrm{CB}$ of $\mathrm{TiO}_{2}$ electrode). Thus, this pathway can also be called the "two-step" or "indirect" electron-injection pathway. To achieve efficient electron injection from the excited dye to the $\mathrm{CB}$ of the $\mathrm{TiO}_{2}$ electrode, the LUMO energy level of the dye for type-I DSSC must be higher (more negative) than the energy level $\left(E_{\mathrm{cb}}\right)$ of the $\mathrm{CB}(-0.5 \mathrm{~V}$ versus the normal hydrogen electrode (NHE)) of the $\mathrm{TiO}_{2}$ electrode (some researchers have proposed that an energy 


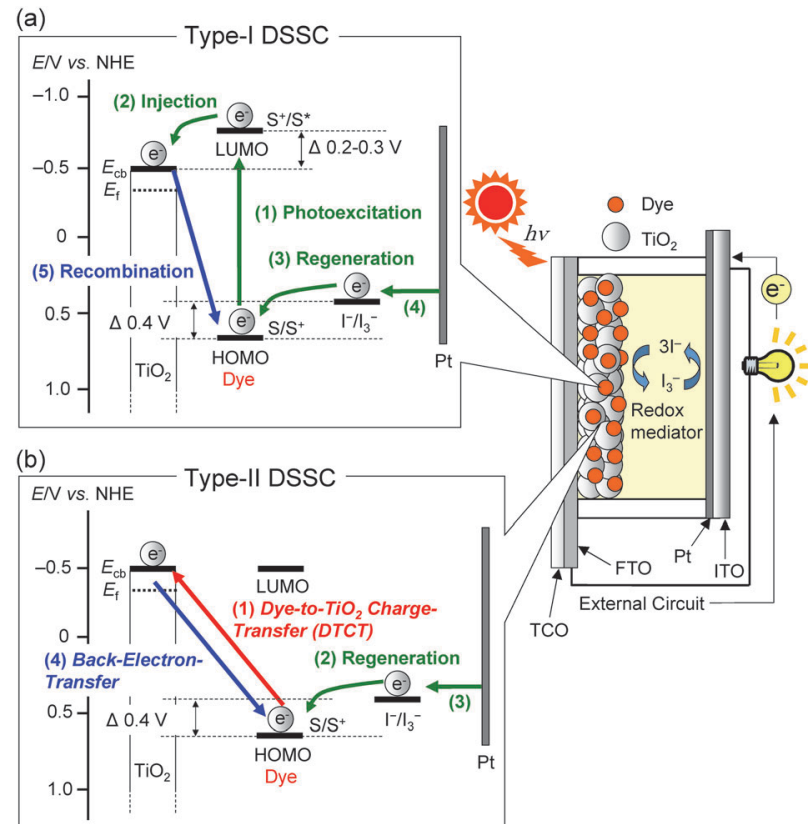

Fig. 1 Schematic representation of construction and operational principle of a typical $\mathrm{TiO}_{2}$-based DSSC (FTO: fluorine-doped $\mathrm{SnO}_{2}$, ITO: tin-doped indium oxide coated glass, TCO: transparent conductive oxide glass), and the pathway for electron injection from the dye to the $\mathrm{CB}$ of the $\mathrm{TiO}_{2}$ electrode. (a) Type-I DSSC, in which an electron is excited from the HOMO to the LUMO level of the dye, followed by injection into the $\mathrm{CB}$ of the $\mathrm{TiO}_{2}$ electrode. (b) Type-II DSSC, in which an electron is injected directly from the $\mathrm{HOMO}$ of the dye into the $\mathrm{CB}$ of the $\mathrm{TiO}_{2}$ electrode upon photoexcitation.

gap of over $0.2-0.3 \mathrm{~V}$ is necessary for efficient electron injection). ${ }^{3-5}$ Almost all dye sensitizers developed so far for type-I DSSCs have carboxyl groups as anchoring groups, which are usually bound to the $\mathrm{TiO}_{2}$ electrode through the bidentate bridging linkage between the carboxyl group of the dye and the Brønsted acid site (surface-bound hydroxyl groups, Ti-OH) on the $\mathrm{TiO}_{2}$ surface (Fig. 2a). Ru complexes, ${ }^{1,9,10}$ porphyrin dyes, ${ }^{11-13}$ phthalocyanine dyes, ${ }^{14}$ and organic dyes ${ }^{3,4,6,15-17}$ bearing carboxyl groups have been known to inject electrons into the $\mathrm{TiO}_{2}$ electrode, according to the type-I pathway. Among dye sensitizers bearing carboxyl groups used so far in type-I DSSCs, donor-acceptor- $\pi$-conjugated $(\mathrm{D}-\pi-\mathrm{A})$ dyes, which are constructed of a diphenyl- or dialkylamino group as the electron donor (D) and a carboxyl group as the electron acceptor (A) and anchor linked by $\pi$-conjugated bridges,

(a)

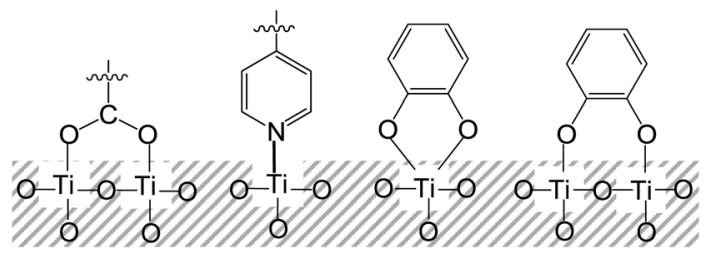

Fig. 2 Possible binding modes of carboxyl group, pyridyl group and catechol on $\mathrm{TiO}_{2}$ surface. (a) A bidentate bridging linkage for carboxyl group, (b) a coordination bond for pyridyl group, (c) a bidentate mononuclear chelating linkage and (d) a bidentate dinuclear bridging linkage for catechol. would be especially expected to be one of the most promising classes of organic dye sensitizers for type-I DSSCs because the wide variety of structures and the facile modification provide potential for molecular design, with the introduction of substituents onto the chromophore skeletons allowing easy control not only of their photophysical and electrochemical properties (the highest occupied molecular orbital (HOMO) and the lowest unoccupied molecular orbital (LUMO) energy levels), but also of their stereochemical structures. As a noteworthy structural feature of $\mathrm{D}-\pi-\mathrm{A}$ dyes, the HOMO is localized over the $\pi$-conjugated system close to the D moiety, and the LUMO is localized over the A moiety. ${ }^{3,4,6}$ Therefore, in light of the D- $\pi-A$ structure concept, the expansion of $\pi$-conjugation and the increase in the electrondonating and electron-accepting abilities of $\mathrm{D}$ moieties and A moieties, respectively, leads to the decrease in the energy gap between the HOMO and LUMO. Moreover, the photoabsorption properties of a $\mathrm{D}-\pi-\mathrm{A}$ dye are associated with intramolecular charge transfer (ICT) excitation from the D to the A moiety of the dye, resulting in efficient electron transfer from the excited dye through the acceptor moiety (carboxyl group) into the CB of $\mathrm{TiO}_{2}$ electrode. Moreover, $\mathrm{D}-\pi-\mathrm{A}$ dyes can facilitate the ICT and the subsequent charge separation of the $\mathrm{D}$ and $\mathrm{A}$ moieties in the excited dye, and rapidly inject electrons into the $\mathrm{CB}$ of $\mathrm{TiO}_{2}$ and effectively retard the charge recombination because the cationic charge on the D moiety of the excited dye is spatially separated by the $\pi$-conjugated bridge from the $\mathrm{TiO}_{2}$ surface with the injected electrons.

On the other hand, we have reported that a new type of D- $\pi-\mathrm{A}$ dye sensitizers bearing a pyridyl group as an electron-withdrawing anchoring group are predominantly adsorbed on the $\mathrm{TiO}_{2}$ electrode through the coordination bond between the pyridyl group of the dye and the Lewis acid site (exposed $\mathrm{Ti}^{n+}$ cations) on the $\mathrm{TiO}_{2}$ surface (Fig. 2b). ${ }^{18,19}$ It was revealed that the new type of $\mathrm{D}-\pi-\mathrm{A}$ dye sensitizers can inject electrons efficiently from the pyridyl group to the $\mathrm{CB}$ of the $\mathrm{TiO}_{2}$ electrode through the coordination bond, compared to the bidentate bridging linkages of conventional $D-\pi-A$ dye sensitizers bearing a carboxyl group. We demonstrated that the pyridyl group is a promising candidate as not only an electron-withdrawing anchoring group but also an electron-injecting group for type-I $D-\pi-A$ dye sensitizers, compared to the carboxyl groups. Recently, some researchers reported that type-I DSSCs based on porphyrin dyes and D- $\pi$-A dyes bearing pyridyl groups. ${ }^{20,21}$ Consequently, much effort has been made on the development of various types of D- $\pi-A$ organic dye sensitizers for type-I DSSCs and there has been a gradual accumulation of information about the relationship between the chemical structures and the photovoltaic performances of type-I DSSCs. As a result, type-I DSSCs have achieved an $\eta$ value of up to $13 \% .{ }^{12 c, d}$ However, as mentioned above, to achieve electron injection from the excited dye to the $\mathrm{CB}$ of the $\mathrm{TiO}_{2}$ electrode for type-I DSSCs, the LUMO levels of the type-I dye sensitizers must be higher than in the CB of the $\mathrm{TiO}_{2}$ electrode. Thus, the restriction of the LUMO levels results in low light harvesting efficiency (LHE).

In contrast, the electron-injection pathway for type-II DSSCs is direct, that is, "one-step" electron injection from the ground 
state of the dye to the $\mathrm{CB}$ of $\mathrm{TiO}_{2}$ by photoexcitation of the dyeto- $\mathrm{TiO}_{2}$ charge transfer (DTCT) bands (Fig. 1b: i.e., an electron is injected directly from the HOMO of the dye into the CB of $\mathrm{TiO}_{2}$ electrode upon photoexcitation). ${ }^{4 b}$ Catechol (Cat) dyes, such as dopamine and fluorine, numerous natural pigments, such as bromopyrogallol red, and anthocyanins containing Cat moieties, which are classified as type-II dye sensitizers, show strong new absorption bands in the longer wavelength region corresponding to the DTCT upon binding to the $\mathrm{TiO}_{2}$ surface. ${ }^{22-29}$ The Cat dyes have been known to bind to the $\mathrm{TiO}_{2}$ surface through a bidentate mononuclear chelating linkage and/or a bidentate binuclear bridging linkage at the Brønsted acid site on $\mathrm{TiO}_{2}$ (Fig. 2c and d). The most advantageous aspect of type-II DSSCs over type-I DSSCs is their light-harvesting capabilities over the wide spectral range of sunlight because the direct electron injection in type-II DSSCs can lead to the creation of a broad DTCT band and the easing of restrictions on the LUMO levels of the dye sensitizers relative to type-I DSSCs with an indirect electron-injection pathway, although the absorption coefficient of the DTCT band for type-II dye sensitizers is much lower than in the absorption band based on the $\pi \rightarrow \pi^{*}$ transition for conventional dye sensitizers due to lower overlap of the ground (molecular-localized) and the excited state (Ti-localized) wave functions. ${ }^{30 a}$ However, the photovoltaic performance of type-II DSSCs based on Cat dyes is significantly lower than in type-I DSSCs based on D- $\pi-A$ organic dye sensitizers. Fundamental studies for the interfacial electron transfer dynamics of Cat dyes adsorbed on $\mathrm{TiO}_{2}$ nanoparticles have revealed that the back-electron transfer (charge recombination) of electrons injected into the $\mathrm{TiO}_{2}$ electrode for the type-II pathway takes place in a subpicosecond timescale, which was significantly faster than in the type-I pathway ( $\mu s-\mathrm{ms})$. Thus, type-II Cat dyes have rarely been employed as sensitizers for DSSCs and thus there have been few attempts to develop type-II Cat dye sensitizers. In fact, the $\eta$ values of type-II DSSCs based on Cat dyes had never exceeded $2.5 \% .^{30 b}$ In an attempt to overcome this problem, Yoon and co-workers showed that attaching electron-donating moieties to the Cat unit can lead to retardation of the backelectron-transfer rate and a dramatic increase in electroninjection efficiency, and a red-shift of the DTCT band caused by the increase in the donor strength of the dye. ${ }^{27 a}$ Their work inspired us to conceive the application of the molecular design of $\mathrm{D}-\pi$-Cat dye sensitizers with strong electron donors, such as triphenylamine, indoline, and carbazole, which is one of the most promising strategies not only to inhibit back electron transfer, but also to enhance direct electron-injection efficiency in type-II DSSCs based on Cat dyes. Thus, to provide a direction in molecular design of Cat dye sensitizers for type-II DSSCs, in our previous work, we designed and synthesized a $D-\pi$-Cat dye, which shows a broad absorption band corresponding to the DTCT upon binding to $\mathrm{TiO}_{2}$ film. ${ }^{29 a}$ It was found that the photocurrent for the DSSC based on the D- $\pi$-Cat dye is mainly generated by a direct electron-injection pathway from the D- $\pi$-Cat dye to the CB of the $\mathrm{TiO}_{2}$ electrode, that is, type-II DSSCs. Moreover, we have demonstrated that the stabilization of the LUMO level and the expansion of the $\pi$-conjugated system by the introduction of a long $\pi$-bridge such as terthiophene on the Cat moiety can lead to an increase in the ICT excitation based on the $\pi-\pi^{*}$ transition with a decrease in the DTCT characteristics, resulting in enhancement of an indirect electron injection pathway from the excited dye to the CB of the $\mathrm{TiO}_{2}$ electrode by photoexcitation of the local band of the adsorbed dye on the $\mathrm{TiO}_{2}$ surface. Interestingly, Nagata et al. reported that a DSSC based on 2-anthroic acid exhibits the type-II pathway with an $\eta$ value of $2.2 \% .^{30 b}$ Thus, the combination of the two injection (direct and indirect) mechanisms with some dye sensitizers has been investigated. ${ }^{24,30}$ To study the electronic injection mechanism in more depth and to generalize the main differences between the type-I and type-II pathways, Sanz and co-workers studied five organic dyes of increasing size, Cat, 2,3-naphthalenediol, alizarin, coumarin C343 having a carboxylic acid group, and coumarin derivative NKX-2311 having a cyanoacrylic acid group, and the electronic structures and optical response of the five dyes attached to the $\mathrm{TiO}_{2}$ electrode were analyzed and compared by using time-dependent density functional theory (TDDFT). ${ }^{24 b}$ From their analysis, NKX-2311 and Cat show purely indirect (type-I pathway) and direct (type-II pathway) electron-injection behavior, respectively. In the sequence from Cat to 2,3-naphthalenediol, C343, alizarin, and NKX-2311, the electron injection changes from a purely direct mechanism to a purely indirect mechanism. Alizarin and $\mathbf{C 3 4 3}$ represent intermediate behavior in which both injection regimes are present. Consequently, the electron injection mechanisms are related to the relative position of the LUMO energy of the dye to the edge of the CB of $\mathrm{TiO}_{2}$ electrode.

Therefore, on the basis of the useful knowledge about the molecular design of $\mathrm{D}-\pi-\mathrm{A}$ dye sensitizers with a pyridyl group for type-I DSSC and D- $\pi$-Cat dye sensitizers with a Cat unit for type-II DSSC obtained from the our previous study, ${ }^{18,19,29}$ in this work, we have designed and developed a type-I/type-II hybrid dye sensitizer OF-Py-Cat with a pyridyl group and a catechol unit as the anchoring group possessing the ability to adsorb on the $\mathrm{TiO}_{2}$ electrode through both a coordination bond at the Lewis acid sites and a bidentate binuclear bridging linkage at the Brønsted acid sites on the $\mathrm{TiO}_{2}$ surface (Fig. 3). It would be expected that the type-I/type-II hybrid dye sensitizer makes it possible to inject electrons into the $\mathrm{CB}$ of the $\mathrm{TiO}_{2}$ electrode by the ICT excitation (type-I pathway) and by the photoexcitation of the DTCT band (type-II pathway). Furthermore, not only to gain insight into the influence of the molecular structure of type-I/type-II hybrid dye sensitizer on the appearance of ICT and DTCT bands and the electron-injection mechanism, but also to investigate the impacts of the ICT and DTCT characteristics of the type-I/type-II hybrid dye sensitizer on the photovoltaic performances of DSSCs, we also synthesized a type-I dye sensitizer OF-Car-Car with two carboxyl groups, a type-I dye sensitizer OF-Py-Car with a pyridyl group and a carboxyl group, a type-II dye sensitizer OF-Cat-Cat with two catechol units, as well as a type-I dye sensitizer OF-Py-Py (YNI-2) with two pyridyl groups. ${ }^{18 d}$ It was found that the type-I/type-II hybrid dye sensitizer adsorbed on $\mathrm{TiO}_{2}$ film exhibits a broad photoabsorption 

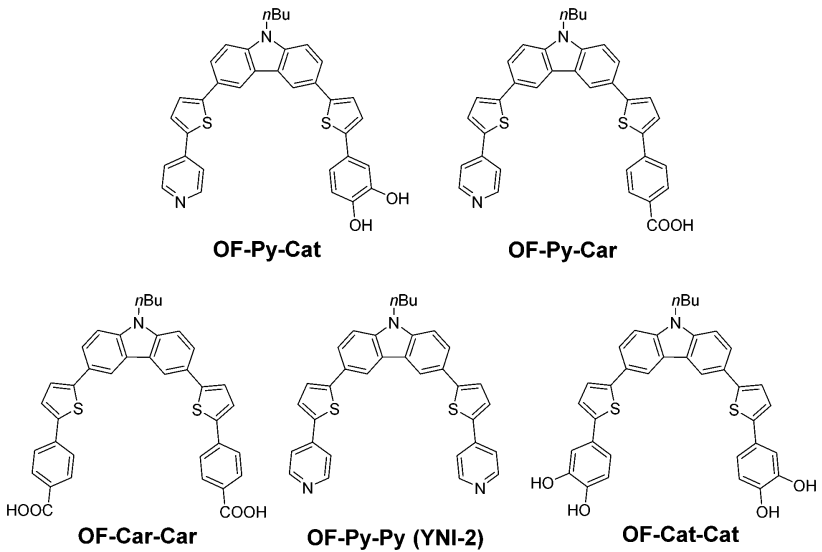

Fig. 3 Chemical structures of OF-Py-Cat, OF-Py-Car, OF-Car-Car, OF-Py-Py (YNI-2) and OF-Cat-Cat.

band originating from the ICT and DTCT characteristics. Here we reveal the photophysical and electrochemical properties of the type-I/type-II hybrid dye sensitizers bearing a pyridyl group and a Cat unit, along with their adsorption mode onto $\mathrm{TiO}_{2}$ film, and their photovoltaic performances in type-I/type-II DSSC, based on optical (photoabsorption and fluorescence spectroscopy) and electrochemical measurements (cyclic voltammetry), density functional theory (DFT) calculation, FT-IR spectroscopy of the dyes adsorbed on $\mathrm{TiO}_{2}$ film, photocurrent-voltage $(I-V)$ curves, incident photon-to-current conversion efficiency (IPCE) spectra, and electrochemical impedance spectroscopy (EIS) for DSSC.

\section{Results and discussion}

\section{Synthesis}

The type-I dye sensitizer OF-Py-Py (YNI-2) ${ }^{18 d}$ with two pyridyl groups was prepared by Stile coupling of 3,6-dibromo-9-butyl$9 H$-carbazole with 4-(5-tributylstannanyl-thiophen-2-yl)-pyridine. In this work, to develop a new synthetic route to $\mathrm{D}-\pi-\mathrm{A}$ dye sensitizers with two anchoring groups, we adopted a synthetic strategy utilizing Suzuki coupling for the synthesis of the D- $\pi-A$ dye sensitizers employed (Scheme 1). Indeed, the type-I/type-II hybrid dye sensitizer OF-Py-Cat and the type-I dye sensitizer OF-Py-Car with two different anchoring groups were successfully prepared by using Suzuki coupling twice to introduce the anchoring (electron acceptor) moiety, where 3-bromo-9-butyl$9 H$-carbazole ${ }^{31}$ and (9-butyl-9H-carbazol-3-yl)boronic acid pinacol ester, ${ }^{31}$ respectively, as starting materials were employed. Moreover, 3,6-bis(5-bromothiophen-2-yl)-9-butyl-9H-carbazole 8 was synthesized as a useful intermediate capable of introducing anchoring groups, that is, the corresponding anchoring unit was introduced by Suzuki coupling of $\mathbf{8}$ with 4-ethoxycarbonylphenylboronic acid and (3,4-bis(methoxymethoxy)phenyl)boronic acid pinacol
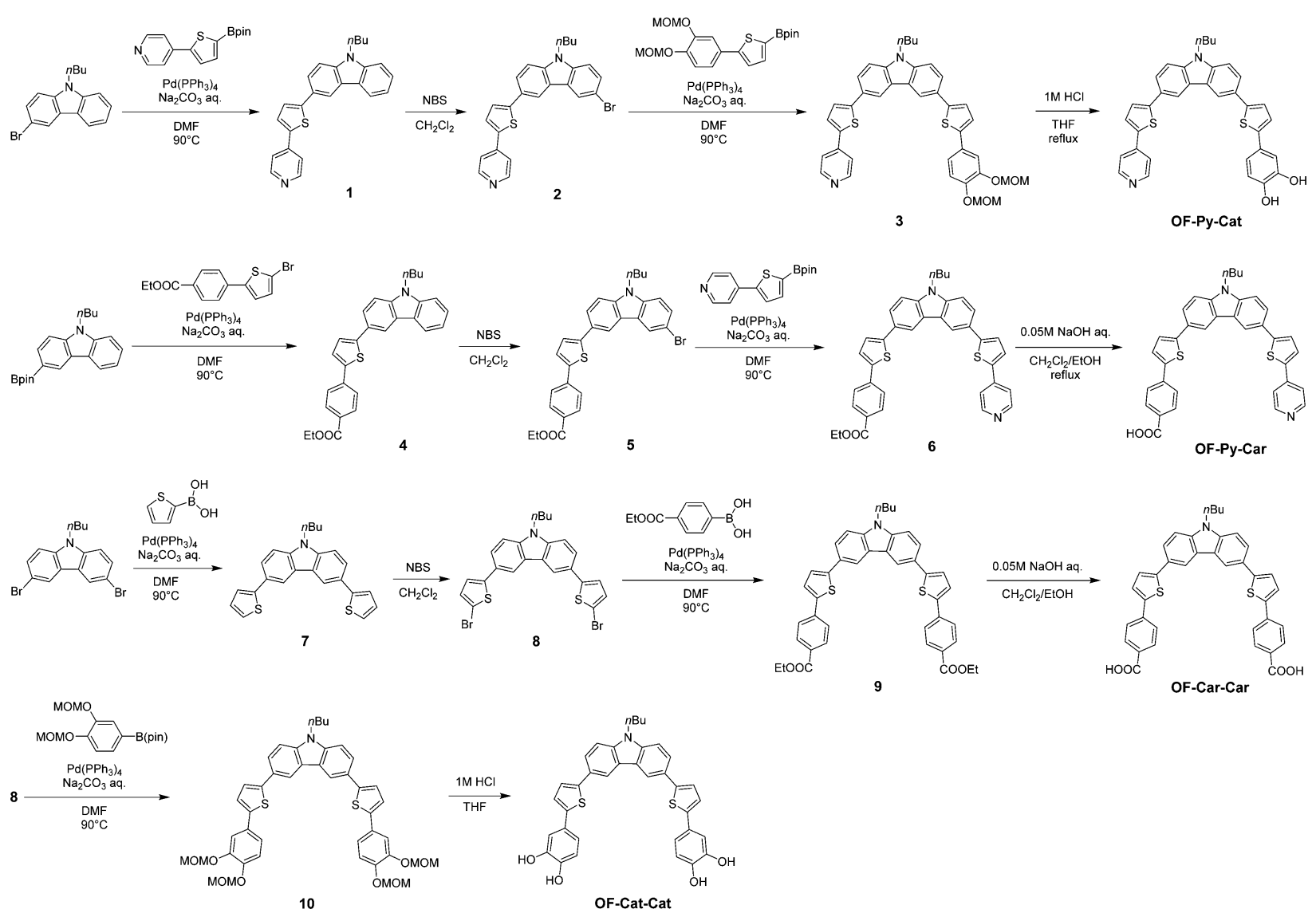

Scheme 1 Synthesis of OF-Py-Cat, OF-Py-Car, OF-Car-Car and OF-Cat-Cat. 
ester to give $\mathbf{9}$ and 10, respectively, which is then treated with the appropriate alkali and acid, respectively, to provide the type-I dye sensitizer OF-Car-Car with two carboxyl groups and the type-II dye sensitizer OF-Cat-Cat with two catechol units.

\section{Photophysical properties in solution}

The UV/vis absorption and fluorescence spectra of OF-Car-Car, OF-Py-Py, OF-Cat-Cat, OF-Py-Car and OF-Py-Cat in THF are shown in Fig. 4 and their spectral data are summarized in Table 1 . The five dyes show a bimodal absorption band with peaks at around 350 and $380 \mathrm{~nm}$ (Fig. 4a). Interestingly, for OFCar-Car, OF-Py-Py and OF-Py-Car with two electron-withdrawing anchoring groups the molar extinction coefficient $(\varepsilon)$ of the absorption band at around $380 \mathrm{~nm}$ is higher than that of the absorption band at around $350 \mathrm{~nm}$, but for OF-Cat-Cat and OF-Py-Cat with a catechol unit as the relatively electrondonating anchoring group, the $\varepsilon$ of the absorption band at around $380 \mathrm{~nm}$ is lower than in the absorption band at around $350 \mathrm{~nm}$. Moreover, the absorption band at around $380 \mathrm{~nm}$ for OF-Cat-Cat is blue-shifted by $c a .10 \mathrm{~nm}$ compared with that of OF-Car-Car, OF-Py-Py and OF-Py-Car. Thus, for the four dyes OF-Car-Car, OF-Py-Py, OF-Py-Car and OF-Py-Cat with an electronwithdrawing anchoring group except OF-Cat-Cat, this result shows that the intense absorption band at the longest wavelength corresponds to the intramolecular charge transfer (ICT) excitation from the carbazole moiety for OF-Car-Car, OF-Py-Py and OF-Py-Car and the carbazole containing a thienylcatechol moiety for OF-Py-Cat, respectively, to the electron-withdrawing
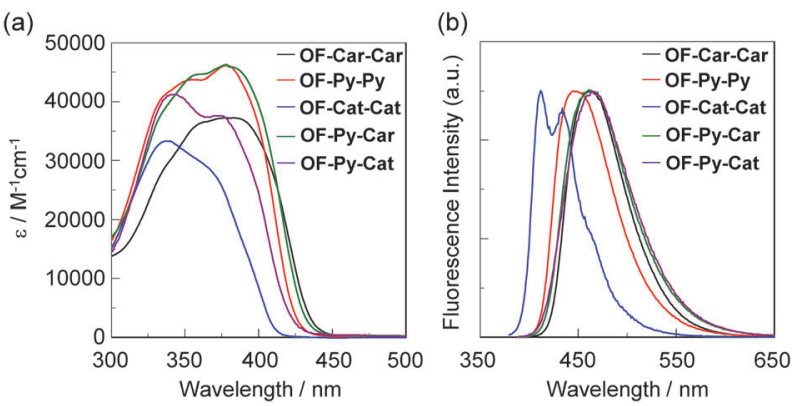

Fig. 4 (a) UV/vis absorption and (b) fluorescence spectra of OF-Car-Car OF-Py-Py, OF-Cat-Cat, OF-Py-Car and OF-Py-Cat in THF. anchoring group. The corresponding fluorescence spectra (Fig. 4b) show that only the dye OF-Cat-Cat exhibits a vibronicstructured fluorescence band $\left(\lambda_{\mathrm{em}}=412 \mathrm{~nm}\right)$, which occurs at a shorter wavelength by $c a$. 35-55 $\mathrm{nm}$ than in the other four dyes $\left(\lambda_{\mathrm{fl}}=c a\right.$. 445-465 nm). Moreover, the dye OF-Cat-Cat $\left(\Phi_{\mathrm{f}}=0.16\right)$ exhibits a lower fluorescence quantum yield $\left(\Phi_{\mathrm{f}}\right)$ than those of the other four dyes $\left(\Phi_{\mathrm{f}}=c a\right.$. 0.5-0.7).

\section{Photophysical properties of dye-adsorbed $\mathrm{TiO}_{2}$ film}

The photoabsorption spectra of the dyes adsorbed on the $\mathrm{TiO}_{2}$ film are shown in Fig. 5a. It is worth noting that in addition to the ICT band observed in THF, OF-Cat-Cat and OF-Py-Cat adsorbed on the $\mathrm{TiO}_{2}$ film show a broad absorption band corresponding to the DTCT upon binding to the $\mathrm{TiO}_{2}$ film, that is, the DTCT band appears in the region of 430 to $650 \mathrm{~nm}$ for OF-Cat-Cat and 450 to $650 \mathrm{~nm}$ for OF-Py-Cat. The red-shift of the absorption peak wavelengths for dyes with a catechol unit upon binding to the $\mathrm{TiO}_{2}$ film can be attributed to the stabilization of the LUMO level of the Ti-Cat dye complexes, which has been demonstrated by DFT calculations in our previous work. ${ }^{29 a}$ As shown in Fig. 5b, the colors of the dyes in THF are light yellow or yellow for OF-Car-Car, OF-Py-Py, OF-Py-Car and OF-Py-Cat, and light purple for OF-Cat-Cat. For OF-Car-Car, OF-Py-Py and OF-Py-Car, the colors of dyes adsorbed on the $\mathrm{TiO}_{2}$ film are similar to those in THF. In contrast, the colors of OF-Cat-Cat and OF-Py-Cat adsorbed on the $\mathrm{TiO}_{2}$ film are almost black and dark-orange, respectively, which indicates a decrease in the transition energy by the appearance of the DTCT band associated with the formation of the surface-bound Ti-Cat complex. Thus, this result reveals that the dye OF-Py-Cat adsorbed on the $\mathrm{TiO}_{2}$ film exhibits a broad photoabsorption band originating from the ICT and DTCT characteristics, that is, the dye OF-Py-Cat can act as a type-I/type-II hybrid dye sensitizer.

\section{Electrochemical properties}

The electrochemical properties of the five dyes were determined by cyclic voltammetry (CV) in DMF containing $0.1 \mathrm{M}$ tetrabutylammonium perchlorate $\left(\mathrm{Bu}_{4} \mathrm{NClO}_{4}\right)$ for OF-Car-Car, OF-Cat-Cat, OF-Py-Car and OF-Py-Cat and THF containing $0.1 \mathrm{M} \mathrm{Bu}_{4} \mathrm{NClO}_{4}$ for OF-Py-Py ${ }^{18 d}$ (Fig. 6). The potentials were referenced to ferrocene/ferrocenium $\left(\mathrm{Fc} / \mathrm{Fc}^{+}\right)$as the internal reference. The oxidation waves for OF-Car-Car, OF-Py-Py and

Table 1 Optical and electrochemical data, HOMO and LUMO energy levels, and DSSC performance parameters of OF dye sensitizers

\begin{tabular}{|c|c|c|c|c|c|c|c|c|c|c|}
\hline Dye & $\lambda_{\max }^{\mathrm{abs}} / \mathrm{nm}\left(\varepsilon / \mathbf{M}^{-1} \mathrm{~cm}^{-1}\right)^{a}$ & $\lambda_{\mathrm{fl}} / \mathrm{nm}\left(\Phi_{\mathrm{f}}\right)^{b}$ & $E_{1 / 2}^{\mathrm{ox}}$ or $E_{\mathrm{onset}}^{\mathrm{ox}} / \mathrm{V}^{c}$ & $\mathrm{HOMO} / \mathrm{V}^{d}$ & $\mathrm{LUMO} / \mathrm{V}^{d}$ & Molecules $/ \mathrm{cm}^{-2 e}$ & $J_{\mathrm{sc}} / \mathrm{mA} \mathrm{cm}^{-2 f}$ & $V_{\mathrm{oc}} / \mathrm{mV}^{f}$ & $\mathrm{ff}^{f}$ & $\eta(\%)^{f}$ \\
\hline OF-Py-Py & $378(46100)$ & $448(0.67)$ & 0.53 & 1.22 & -1.75 & $1.0 \times 10^{17}$ & 5.88 & 542 & 0.64 & 2.04 \\
\hline OF-Py-Car & $378(46200)$ & $464(0.69)$ & 0.55 & 1.27 & -1.65 & $1.1 \times 10^{17}$ & 5.28 & 485 & 0.62 & 1.51 \\
\hline OF-Py-Cat & $373(37600)$ & $465(0.51)$ & 0.15 & 0.87 & -2.05 & $1.2 \times 10^{17}$ & 0.40 & 299 & 0.48 & 0.06 \\
\hline
\end{tabular}

${ }^{a}$ In 1,4-dioxane. ${ }^{b}$ Fluorescence quantum yields $\left(\Phi_{\mathrm{f}}\right)$ were determined by using a calibrated integrating sphere system $\left(\lambda_{\mathrm{ex}}=383,378,370,378\right.$ and $373 \mathrm{~nm}$ for OF-Car-Car, OF-Py-Py, OF-Cat-Cat, OF-Py-Car, and OF-Py-Cat, respectively). ${ }^{c}$ Half-wave potentials versus $\mathrm{Fc} / \mathrm{Fc}^{+}$of oxidation ( $\left.E_{1 / 2}^{\text {ox }}\right)$ for OF-Py-Py were recorded in $\mathrm{THF} / \mathrm{Bu}_{4} \mathrm{NClO}_{4}(0.1 \mathrm{M})$ solution. Onset $\left(E_{\mathrm{onset}}^{\mathrm{ox}}\right)$ versus $\mathrm{Fc} / \mathrm{Fc}^{+}$of the oxidation potential for OF-Car-Car, OF-Cat-Cat, OF-Py-Car, and OF-Py-Cat were recorded in $\mathrm{DMF} / \mathrm{Bu}_{4} \mathrm{NClO}_{4}(0.1 \mathrm{M})$ solution. ${ }^{d}$ Versus normal hydrogen electrode (NHE). ${ }^{e}$ Adsorption amount of dye molecules per unit area of the $\mathrm{TiO}_{2}$ electrode, when the $9 \mu \mathrm{m}$ thick $\mathrm{TiO}_{2}$ electrode was immersed into $0.1 \mathrm{mM}$ dye solution in THF. ${ }^{f}$ Under a simulated solar light (AM 1.5, $100 \mathrm{~mW} \mathrm{~cm}^{-2}$ ). 
(a)

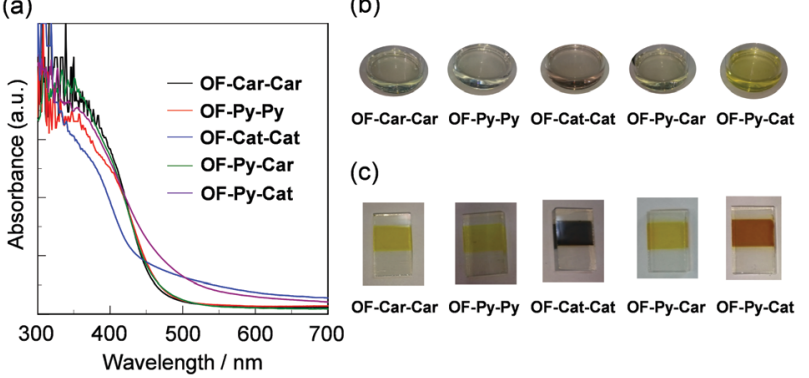

Fig. 5 (a) Photoabsorption spectra of OF-Car-Car, OF-Py-Py, OF-Cat-Cat OF-Py-Car and OF-Py-Cat adsorbed on $\mathrm{TiO}_{2}$ film. Photographs of the dyes (b) in THF and (c) adsorbed on $\mathrm{TiO}_{2}$ film.

(a)

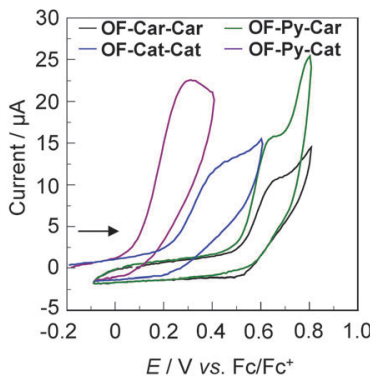

(b)

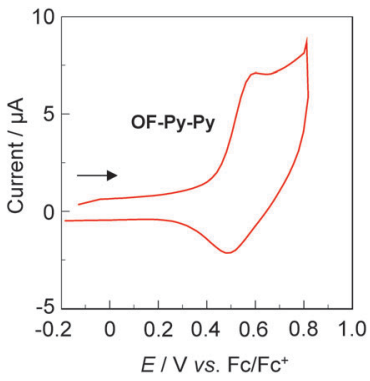

Fig. 6 Cyclic voltammograms of (a) OF-Car-Car, OF-Cat-Cat, OF-Py-Car and OF-Py-Cat in DMF containing $0.1 \mathrm{M} \mathrm{Bu}_{4} \mathrm{NClO}_{4}$ and (b) OF-Py-Py in THF containing $0.1 \mathrm{M} \mathrm{Bu}_{4} \mathrm{NClO}_{4}$. The arrow denotes the direction of the potential scan.

OF-Py-Car were observed at around $0.6 \mathrm{~V}$ versus $\mathrm{Fc} / \mathrm{Fc}^{+}$, whereas the oxidation waves for OF-Cat-Cat and OF-Py-Cat were observed at around $0.4 \mathrm{~V}$ and $0.3 \mathrm{~V}$, respectively, which are cathodically shifted by $0.2 \mathrm{~V}$ and $0.3 \mathrm{~V}$, respectively, compared with those of OF-Car-Car, OF-Py-Py and OF-Py-Car. The corresponding reduction wave was clearly observed at $0.48 \mathrm{~V}$ for OF-Py-Py, whereas a clear reduction wave was not observed for OF-Car-Car, OF-Cat-Cat, OF-Py-Car and OF-Py-Cat. These results show that the redox process of OF-Py-Py is electrochemically reversible, but those of OF-Car-Car, OF-Cat-Cat, OF-Py-Car and OF-Py-Cat are electrochemically irreversible. The HOMO energy levels of the dyes were estimated from the onset $\left(E_{\text {onset }}^{\text {ox }}\right)$ of the oxidation potential for OF-Car-Car $(0.55 \mathrm{~V})$, OF-Cat-Cat $(0.28 \mathrm{~V})$, OF-Py-Car $(0.55 \mathrm{~V})$ and OF-Py-Cat $(0.15 \mathrm{~V})$, and the half-wave potential $\left(E_{1 / 2}^{\text {ox }}=0.53 \mathrm{~V}\right)$ for OF-Py-Py (Table 1$)$. The HOMO energy levels (versus NHE) of OF-Cat-Cat $(1.00 \mathrm{~V})$ and OF-Py-Cat (0.87 V) are higher than in OF-Car-Car, OF-Py-Py and OF-Py-Car (ca. $1.25 \mathrm{~V}$ ). This result shows that the HOMO energy levels are more positive than the $\mathrm{I}_{3}{ }^{-} / \mathrm{I}^{-}$redox potential $(0.4 \mathrm{~V})$, and thus this ensures an efficient regeneration of the oxidized dyes by electron transfer from the $\mathrm{I}_{3}{ }^{-} / \mathrm{I}^{-}$redox couple in the electrolyte. The LUMO energy levels of the dyes were estimated from the $E_{\text {onset }}^{\text {ox }}$ or the $E_{1 / 2}^{\text {ox }}$ and an intersection of the UV/vis absorption and fluorescence spectra $(428 \mathrm{~nm} ; 2.90 \mathrm{eV}$ for OF-Car-Car, $417 \mathrm{~nm}$; $2.97 \mathrm{eV}$ for OF-Py-Py, $398 \mathrm{~nm} ; 3.12 \mathrm{eV}$ for OF-Cat-Cat, $424 \mathrm{~nm}$; $2.92 \mathrm{eV}$ for OF-Py-Car and $418 \mathrm{~nm} ; 2.97 \mathrm{eV}$ for OF-Py-Cat).
The LUMO energy levels of OF-Cat-Cat $(-2.12 \mathrm{~V})$ and OF-Py-Cat $(-2.05 \mathrm{~V})$ are also higher than in OF-Car-Car, OF-Py-Py and OF-Py-Car $(c a .-1.70 \mathrm{~V})$. Therefore, this result shows that from OF-Car-Car, OF-Py-Py and OF-Py-Car to OF-Cat-Cat, that is, by replacing the electron-withdrawing carboxyl and pyridyl groups with the electron-donating catechol unit as the anchoring group, the elevation of the LUMO energy level is larger than that of the HOMO energy level. Consequently, it was revealed that the blue-shift of the ICT absorption band for OF-Cat-Cat relative to OF-Car-Car, OF-Py-Py and OF-Py-Car is attributed to the destabilization of the LUMO energy level by the introduction of two catechol units with electron-donating ability, resulting in an increase in the HOMO-LUMO band gap. Evidently, the LUMO energy levels of the five dyes are higher than the $E_{\mathrm{cb}}$ of the CB of $\mathrm{TiO}_{2}(-0.5 \mathrm{~V})$ electrode, suggesting that an electron injection from the photoexcited dye to the $\mathrm{CB}$ of $\mathrm{TiO}_{2}$ electrode for type-I DSSCs is thermodynamically feasible.

\section{Theoretical calculations}

To examine the electronic structures of OF-Car-Car, OF-Py-Py, OF-Cat-Cat, OF-Py-Car and OF-Py-Cat, the molecular orbitals of these dyes were calculated using density functional theory (DFT) at the B3LYP/6-31G(d,p) level. ${ }^{33}$ The DFT calculations indicate that for OF-Car-Car, OF-Py-Py and OF-Py-Car the HOMOs are mostly localized on the carbazole moiety containing a thiophene ring (Fig. 7). The LUMOs for OF-Car-Car and OF-Py-Py are mostly localized on the two thienylbenzoic acid moieties and the two thienylpyridine moieties, respectively. On the other hand, for OF-Py-Car the LUMO is mostly localized on the thienylbenzoic acid moiety, and the LUMO+1 is mostly localized on the thienylpyridine moiety. Interestingly, for OF-Py-Cat the HOMO is mostly localized on the carbazole containing a thienylcatechol moiety and a thiophene ring, and the LUMO is mostly localized on the thienylpyridine moiety. Moreover, for OF-Cat-Cat the HOMO is delocalized over the whole molecule but the LUMO is mostly localized on the carbazole moiety containing the two thiophene rings. Accordingly, the DFT calculations reveal that for the four dyes with an electron-withdrawing anchoring group, except OF-Cat-Cat, the dye excitations upon light irradiation induce a strong ICT from the carbazole moiety to the electron-withdrawing anchoring groups.

\section{FTIR spectra}

To elucidate the adsorption states of the five dyes on $\mathrm{TiO}_{2}$ nanoparticles, we measured the FTIR spectra of the dye powders and the dyes adsorbed on $\mathrm{TiO}_{2}$ film. For the dye powders of OF-Car-Car and OF-Py-Car (Fig. 8a and d), the $\mathrm{C}=\mathrm{O}$ stretching band of the carboxyl group was observed at $1678 \mathrm{~cm}^{-1}$ for OF-Car-Car and $1695 \mathrm{~cm}^{-1}$ for OF-Py-Car. When the two dyes were adsorbed on the $\mathrm{TiO}_{2}$ surface, the $\mathrm{C}=\mathrm{O}$ stretching bands of the carboxyl group disappeared completely; this indicates the formation of a bidentate bridging linkage between the carboxyl group of the dye and the Brønsted acid site on the $\mathrm{TiO}_{2}$ surface. In addition, for the dye powder of OF-Py-Car the $\mathrm{C}=\mathrm{N}$ stretching band of the pyridyl group was clearly observed at $1601 \mathrm{~cm}^{-1}$. In the FTIR spectrum of OF-Py-Car adsorbed on the $\mathrm{TiO}_{2}$ film, a new band appeared at around $1612 \mathrm{~cm}^{-1}$, which can be 


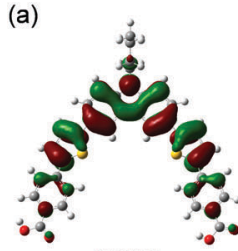

HOMO

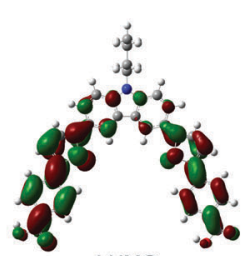

LUMO

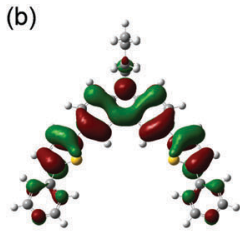

HOMO

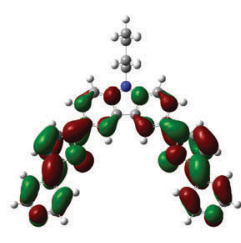

LUMO

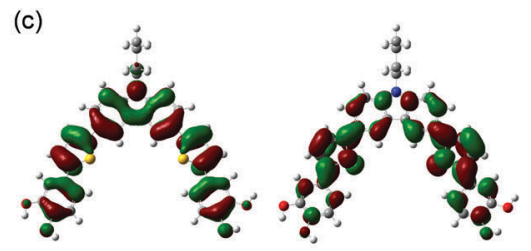

номо
LUMO OF-Car-Car OF-Py-Py OF-Cat-Cat

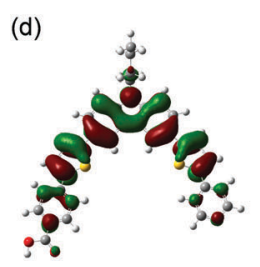

HOMO
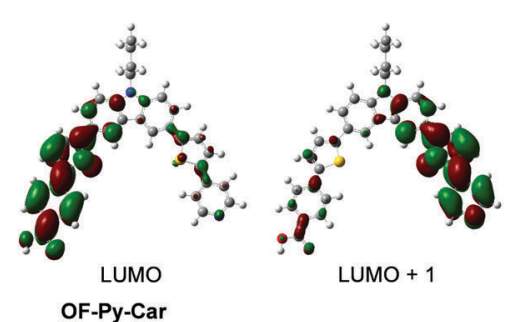

(e)

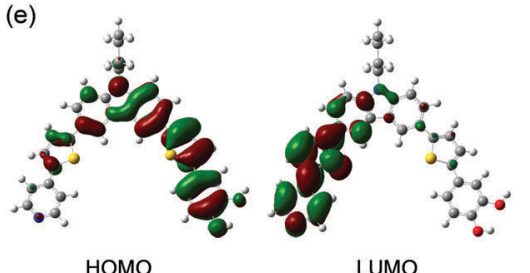

OF-Py-Cat

Fig. 7 HOMO and LUMO of (a) OF-Car-Car, (b) OF-Py-Py, (c) OF-Cat-Cat, (d) OF-Py-Car and (e) OF-Py-Cat derived from the DFT calculations at the B3LYP/6-31G(d,p) level.

(a)

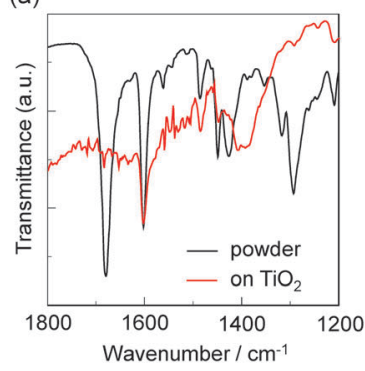

(c)

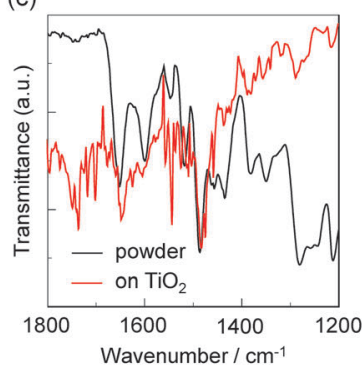

(e)

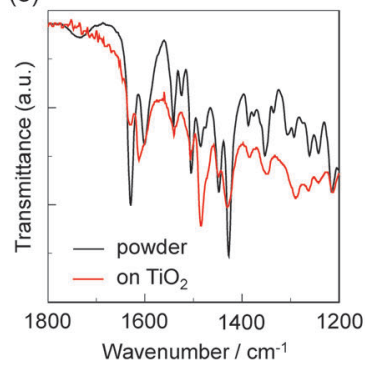

(b)

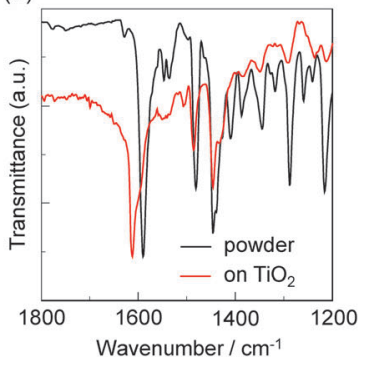

(d)

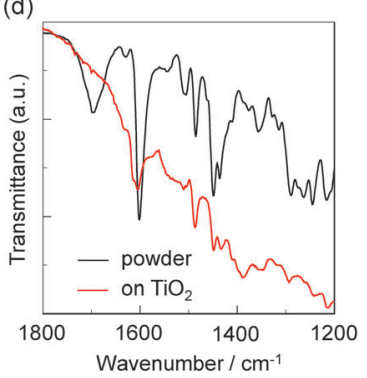

Fig. 8 FTIR spectra of the powders and the dyes adsorbed on $\mathrm{TiO}_{2}$ nanoparticles. (a) OF-Car-Car, (b) OF-Py-Py, (c) OF-Cat-Cat, (d) OF-PyCar and (e) OF-Py-Cat.

assigned to the pyridyl group coordinated to the Lewis acid sites of the $\mathrm{TiO}_{2}$ surface. As reported previously, the FTIR spectrum of OF-Py-Py adsorbed on $\mathrm{TiO}_{2}$ films demonstrated

that the dye OF-Py-Py is predominantly adsorbed on the $\mathrm{TiO}_{2}$ surface through the coordination bond between the pyridyl group of the dye and the Lewis acid site on the $\mathrm{TiO}_{2}$ surface, that is, the fact is based on a new band at around $1614 \mathrm{~cm}^{-1}$ in the FTIR spectrum of OF-Py-Py adsorbed on the $\mathrm{TiO}_{2}$ film (Fig. 8b). ${ }^{18 d}$ Consequently, the dye OF-Py-Car with a pyridyl group and a carboxyl group was adsorbed on the $\mathrm{TiO}_{2}$ surface through both the bidentate bridging linkage between the carboxyl group of the dye and the Brønsted acid site of the $\mathrm{TiO}_{2}$ surface and the coordination bond between the pyridyl group of the dye and the Lewis acid site of the $\mathrm{TiO}_{2}$ surface. On the other hand, for the dye powders of OF-Cat-Cat and OF-Py-Cat (Fig. 8c and e), the stretching vibrations of the phenolic group $(\mathrm{C}-\mathrm{OH})$ for the catechol unit was observed at 1280, 1256 and $1242 \mathrm{~cm}^{-1}$ for OF-Cat-Cat and 1306, 1292, 1260 and $1242 \mathrm{~cm}^{-1}$ for OF-Py-Cat. In the FTIR spectra of dyes adsorbed on $\mathrm{TiO}_{2}$ film, the stretching vibrations merge to one prominent signal or lose their hyperfine structure. Thus, these observations indicate that the two dyes are adsorbed on the $\mathrm{TiO}_{2}$ surface through the formation of a bidentate mononuclear chelating linkage and/or a bidentate binuclear bridging linkage between the Cat unit of dye and the $\mathrm{TiO}_{2}$ surface. ${ }^{28}$ In addition, for the FTIR spectrum of OF-Py-Cat adsorbed on the $\mathrm{TiO}_{2}$ film, a new band appeared at around $1612 \mathrm{~cm}^{-1}$, which can be assigned to the pyridyl group coordinated to the Lewis acid sites of the $\mathrm{TiO}_{2}$ surface. Therefore, the dye OF-Py-Cat with a pyridyl group and a catechol unit was adsorbed on the $\mathrm{TiO}_{2}$ surface through both the bidentate linkage between the catechol unit of the dye and the Brønsted acid site of the $\mathrm{TiO}_{2}$ surface and the coordination bond between the pyridyl group of the dye and the Lewis acid site of the $\mathrm{TiO}_{2}$ surface.

\section{Photovoltaic performances}

The DSSCs based on OF-Car-Car, OF-Py-Py, OF-Cat-Cat, OF-Py-Car and OF-Py-Cat were fabricated by using the dye-adsorbed $\mathrm{TiO}_{2}$ electrode $(9 \mathrm{~mm})$, Pt-coated glass as a counter electrode, and an acetonitrile solution with iodine $(0.05 \mathrm{M})$, lithium iodide $(0.1 \mathrm{M})$, 
(a)

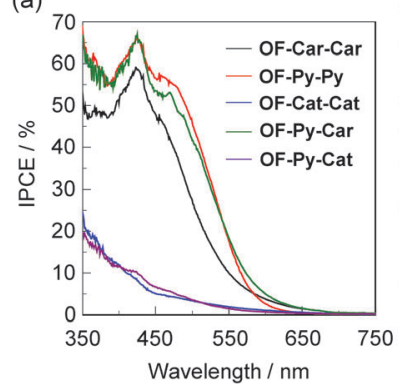

(b)

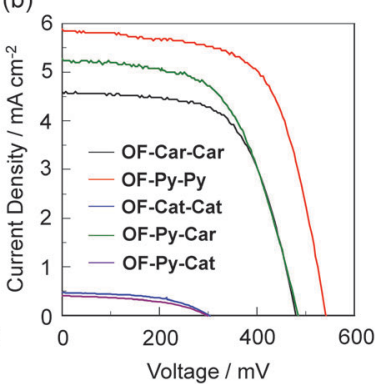

Fig. 9 (a) IPCE spectra and (b) I-V curves of DSSCs based on OF-Car-Car, OF-Py-Py, OF-Cat-Cat, OF-Py-Car and OF-Py-Cat.

and 1,2-dimethyl-3-propylimidazolium iodide $(0.6 \mathrm{M})$ as the electrolyte. The photocurrent-voltage $(I-V)$ characteristics were measured under simulated solar light (AM 1.5, $100 \mathrm{~mW} \mathrm{~cm}^{-2}$ ). The IPCE spectra and the $I-V$ curves are shown in Fig. 9. The photovoltaic performance parameters are collected in Table 1. It is worth mentioning here that the adsorption amount of all the five dyes bearing two anchoring groups adsorbed on the $\mathrm{TiO}_{2}$ electrode is $c a .1 .0 \times 10^{17}$ molecules per $\mathrm{cm}^{2}$, which is comparable to that of conventional dye sensitizers bearing one anchoring group. The IPCE spectra of the DSSCs based on these dyes demonstrated that the IPCE of OF-Car-Car, OF-Py-Py and OF-Py-Car are much higher than those of OF-Cat-Cat and OF-Py-Cat (Fig. 9a). Interestingly, the maximum IPCE values of OF-Py-Py (66\% at $426 \mathrm{~nm})$ and OF-Py-Car (66\% at $428 \mathrm{~nm})$ are somewhat higher than in OF-Car-Car (59\% at $423 \mathrm{~nm})$. For the DSSCs based on OF-Cat-Cat and OF-Py-Cat the DTCT bands make surprisingly little contribution to the IPCE spectra, that is, the IPCE originating from the DTCT band, which is below $10 \%$ in the region of 450 to $600 \mathrm{~nm}$, is observed. The $I-V$ curves show that the short circuit photocurrent density $\left(J_{\mathrm{sc}}\right)$ and $\eta$ increase in the order of OF-Py-Cat $\left(0.40 \mathrm{~mA} \mathrm{~cm}{ }^{-2}, 0.06 \%\right) \approx$ OF-Cat-Cat $\left(0.47 \mathrm{~mA} \mathrm{~cm}^{-2}, 0.07 \%\right)<$ OF-Car-Car $\left(4.60 \mathrm{~mA} \mathrm{~cm}^{-2}\right.$, $1.37 \%)<$ OF-Py-Car (5.28 mA cm $\left.\mathrm{cm}^{-2}, 1.51 \%\right)<$ OF-Py-Py (5.88 $\mathrm{mA} \mathrm{cm}^{-2}, 2.04 \%$ ) (Fig. 9b). Thus, this result demonstrates that the photovoltaic performances of DSSC based on OF-Py-Car and OF-Py-Py with at least a pyridyl group are higher than in OF-Car-Car with only carboxyl group, which is attributed to efficient electron injection from the pyridyl group to the $\mathrm{CB}$ of the $\mathrm{TiO}_{2}$ electrode through the coordination bond at the Lewis acid sites on the $\mathrm{TiO}_{2}$ surface, compared to the carboxyl group through the bidentate bridging linkages at the Brønsted acid sites on the $\mathrm{TiO}_{2}$ surface. On the other hand, the significantly low photovoltaic performance of DSSC based on OF-Cat-Cat with the two catechol units is due to the facilitation of the back-electron transfer from the electrons injected into $\mathrm{TiO}_{2}$ to the oxidized dye. Moreover, the most important finding to be emphasized is that the totally unexpected result for DSSC based on OF-Py-Cat with both a pyridyl group and a catechol unit may be due to significantly faster back-electron transfer, in spite of the efficient electron injection from the pyridyl group to the $\mathrm{CB}$ of the $\mathrm{TiO}_{2}$ electrode.

On the other hand, it is also worth mentioning here that the open-circuit photovoltage $\left(V_{\text {oc }}\right)$ values of DSSC based on OF-Cat-Cat

(a)

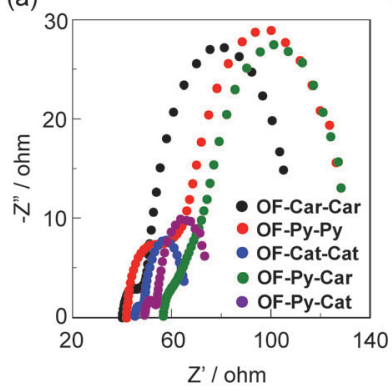

(b)

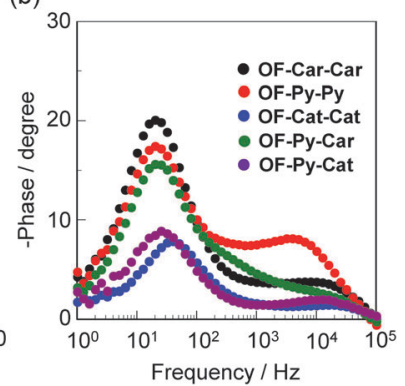

Fig. 10 (a) Nyquist plots and (b) Bode phase plots of DSSCs based on OF-Car-Car, OF-Py-Py, OF-Cat-Cat, OF-Py-Car and OF-Py-Cat.

(304 mV) and OF-Py-Cat $(299 \mathrm{mV})$ with a catechol unit are much lower than in OF-Car-Car $(480 \mathrm{mV})$, OF-Py-Py $(542 \mathrm{mV})$ and OF-Py-Car (485 mV). Thus, electrochemical impedance spectroscopy (EIS) analysis was performed to study the electron recombination process in DSSCs based on the dyes in the dark under a forward bias of -0.35 or $-0.55 \mathrm{~V}$ with a frequency range of $1 \mathrm{~Hz}$ to $100 \mathrm{kHz}$. The large semicircle in the Nyquist plot (Fig. 10a), which corresponds to the midfrequency peaks in the Bode phase plots, represents the charge recombination between the injected electrons into the $\mathrm{TiO}_{2}$ electrode and $\mathrm{I}_{3}{ }^{-}$ ions in the electrolyte, that is, the charge-transfer resistances at the $\mathrm{TiO}_{2} /$ dye/electrolyte interface. The Nyquist plots show that the electron resistance $\left(R_{\mathrm{rec}}\right)$ value of the large semicircle for OF-Car-Car (64 $\Omega$ ), OF-Py-Py (68 $\Omega$ ) and OF-Py-Car $(50 \Omega)$ is higher than in OF-Cat-Cat $(16 \Omega)$ and OF-Py-Cat $(20 \Omega)$, indicating that the DSSCs with high $V_{\text {oc }}$ values have a tendency to exhibit a large $R_{\text {rec }}$ value. The electron recombination lifetimes $\left(\tau_{\mathrm{e}}\right)$, which are an expression of the electron recombination between the injected electrons into $\mathrm{TiO}_{2}$ and $\mathrm{I}_{3}{ }^{-}$ions in the electrolyte, are extracted from the angular frequency $\left(\omega_{\text {re }}\right)$ at the mid-frequency peak in the Bode phase plot (Fig. 10b) using $\tau_{\mathrm{e}}=1 / \omega_{\text {rec }}$. The $\tau_{\mathrm{e}}$ value (8 ms) for OF-Car-Car, OF-Py-Py and OF-Py-Car is higher than in OF-Cat-Cat (4 ms) and OF-Py-Cat $(6 \mathrm{~ms})$, that is, the $\tau_{\mathrm{e}}$ values have the same tendency as the $R_{\text {rec }}$ values. This result revealed that the charge recombination between the injected electrons into the $\mathrm{TiO}_{2}$ electrode and $\mathrm{I}_{3}{ }^{-}$ions in the electrolyte may be one of the major reasons for the difference in $V_{\mathrm{oc}}$ value between the DSSC based on the five dyes, that is, the dyes OF-Car-Car, OF-Py-Py and OF-Py-Car can effectively retard the charge recombination compared with OF-Cat-Cat and OF-Py-Cat, but the decrease in the number of electrons injected into the CB of the $\mathrm{TiO}_{2}$ electrode results in a lower $V_{\mathrm{oc}}$ value for the DSSC based on OF-Cat-Cat and OF-Py-Cat. ${ }^{3,4}$ Consequently, on the basis of the photophysical and electrochemical properties, the dye-adsorption modes onto $\mathrm{TiO}_{2}$ film and the photovoltaic performances for OF-Car-Car, OF-Py-Py, OF-Cat-Cat, OF-Py-Car and OF-Py-Cat, this work develops a new concept of the molecular design and synthesis of a type-I/type-II hybrid dye sensitizer capable of efficiently injecting electrons and with good lightharvesting features, although the photovoltaic performance of the DSSC based on the type-I/type-II hybrid dye sensitizer with a pyridyl group and a catechol unit that has been developed in 
this current stage is much lower than in DSSCs based on type-I dye sensitizers with two carboxyl groups, two pyridyl groups, or both a pyridyl group and a carboxyl group.

\section{Conclusions}

Working toward the creation of a type-I/type-II hybrid dye sensitizer for dye-sensitized solar cells (DSSCs) that makes it possible to inject electron into the conduction band (CB) of the $\mathrm{TiO}_{2}$ electrode by intramolecular charge-transfer (ICT) excitation (type-I pathway) and by the photoexcitation of the dye-to$\mathrm{TiO}_{2}$ charge transfer (DTCT) band (type-II pathway), we have designed and developed the dye sensitizer OF-Py-Cat with a pyridyl group and a catechol unit as the anchoring group possessing the ability to adsorb on the $\mathrm{TiO}_{2}$ electrode through both the coordination bond at the Lewis acid sites and the bidentate binuclear bridging linkage at the Brønsted acid sites on the $\mathrm{TiO}_{2}$ surface. Furthermore, not only to gain insight into the influence of the molecular structure of the type-I/type-II hybrid dye sensitizer on the appearance of the ICT and DTCT bands and the electron-injection mechanism, but also to investigate the impacts of the ICT and DTCT characteristics of type-I/ type-II hybrid dye sensitizer on the photovoltaic performances of DSSCs, type-I dye sensitizer OF-Car-Car with two carboxyl groups, type-I dye sensitizer OF-Py-Py with two pyridyl groups, type-I dye sensitizer OF-Py-Car with a pyridyl group and a carboxyl group, and type-II dye sensitizer OF-Cat-Cat with two catechol units have been also synthesized. It was found that the dye OF-Py-Cat adsorbed on the $\mathrm{TiO}_{2}$ film exhibits a broad photoabsorption band originating from the ICT and DTCT characteristics, that is, the dye OF-Py-Cat can act as a type-I/ type-II hybrid dye sensitizer. However, the photovoltaic performance of the type-I/type-II DSSC based on OF-Py-Cat is lower than in the type-I DSSC based on the dye sensitizers (OF-Car-Car, OF-Py-Py, and OF-Py-Car) with a carboxyl group or a pyridyl group, but is equivalent to that of type-II DSSC based on the dye sensitizer (OF-Cat-Cat) with a catechol unit. On the basis of the photophysical and electrochemical properties, the dyeadsorption modes onto $\mathrm{TiO}_{2}$ film and the photovoltaic performances for OF-Car-Car, OF-Py-Py, OF-Cat-Cat, OF-Py-Car and OF-Py-Cat, we revealed that the low photovoltaic performance of the DSSC based on OF-Py-Cat may be due to significantly faster back-electron transfer from the electrons injected into $\mathrm{TiO}_{2}$ electrode to the oxidized dye, in spite of the efficient electron injection from the pyridyl group to the $\mathrm{CB}$ of $\mathrm{TiO}_{2}$ electrode, which is the most important finding to be emphasized in this work. Consequently, this work develops a new concept of the molecular design and synthesis of a type-I/type-II hybrid dye sensitizer capable of efficiently injecting electrons and good light-harvesting feature, and thus in order to provide a direction in the molecular design of the high performance type-I/type-II hybrid dye sensitizer, further study to gain greater insight into the effects of the molecular structure of type-I/type-II hybrid dye sensitizer on the appearance of the ICT and DTCT characteristics, and the photovoltaic performances is now in progress by developing dye sensitizers bearing the substitutedpyridyl group and -catechol unit.

\section{Experimental}

\section{General}

Melting points were measured with a Yanaco micro melting point apparatus MP model. IR spectra were recorded on a PerkinElmer Spectrum One FT-IR spectrometer by ATR method. High-resolution mass spectral data were acquired on a Thermo Fisher Scientific LTQ Orbitrap XL. High-resolution gas chromatography-time of flight mass spectral data (GC-TOFMS) were acquired on a JMS-T100 GCV 4G (JEOL). ${ }^{1} \mathrm{H}$ NMR and ${ }^{13} \mathrm{C}$ NMR spectra were recorded on a Varian-400 $(400 \mathrm{MHz})$ or a Varian-500 $(500 \mathrm{MHz})$ FT NMR spectrometer. Absorption spectra were observed with a Shimadzu UV-3150 spectrophotometer and fluorescence spectra were measured with a HORIBA FluoroMax-4 spectrofluorometer. The fluorescence quantum yields in solution were determined by a HORIBA FluoroMax-4 spectrofluorometer by using a calibrated integrating sphere system $\left(\lambda_{\mathrm{ex}}=383,378,370,378\right.$ and $373 \mathrm{~nm}$ for OF-Car-Car, OF-Py-Py, OF-Cat-Cat, OF-Py-Car, and OF-Py-Cat, respectively). Cyclic voltammetry (CV) curves were recorded in $\mathrm{THF} / \mathrm{Bu}_{4} \mathrm{NClO}_{4}(0.1 \mathrm{M})$ solution for OF-Py-Py and $\mathrm{DMF} / \mathrm{Bu}_{4} \mathrm{NClO}_{4}$ (0.1 M) solution for OF-Car-Car and OF-Cat-Cat, OF-Py-Car, and OF-Py-Cat with a three-electrode system consisting of $\mathrm{Ag} / \mathrm{Ag}^{+}$as the reference electrode, a Pt plate as the working electrode, and Pt wire as the counter electrode by using an Electrochemical Measurement System HZ-7000 (HOKUTO DENKO). The HOMO and LUMO energy levels of OF-Car-Car and OF-Py-Py, OF-Cat-Cat, OF-Py-Car, and OF-Py-Cat were evaluated from the spectral analyses and the CV data (the HOMO energy level was evaluated from the $E_{\text {onset }}^{\text {ox }}$ of the oxidation potential or the $E_{1 / 2}^{\text {ox }}$ ). The LUMO energy level was estimated from the $E_{\text {onset }}^{\text {ox }}$ or the $E_{1 / 2}^{\text {ox }}$ and an intersection of absorption and fluorescence spectra $(428 \mathrm{~nm}$; $2.90 \mathrm{eV}$ for OF-Car-Car, $417 \mathrm{~nm}$; $2.97 \mathrm{eV}$ for OF-Py-Py, $398 \mathrm{~nm}$; $3.12 \mathrm{eV}$ for OF-Cat-Cat, $424 \mathrm{~nm} ; 2.92 \mathrm{eV}$ for OF-Py-Car and $418 \mathrm{~nm} ; 2.97 \mathrm{eV}$ for OF-Py-Cat) in THF, that is, the LUMO energy level was obtained through the equation $-\left[E_{0-0}-\right.$ HOMO $]$, where the $E_{0-0}$ transition energy is an intersection of the absorption and fluorescence spectra corresponding to the energy gap between the HOMO and the LUMO. Electrochemical impedance spectroscopy (EIS) for DSSCs in the dark under a forward bias of -0.35 or $-0.55 \mathrm{~V}$ with a frequency range of $1 \mathrm{~Hz}$ to $100 \mathrm{kHz}$ was measured with an AMETEK Versa STAT 3.

\section{Synthesis}

9-Butyl-3-(5-(pyridin-4-yl)thiophen-2-yl)-9H-carbazole (1). To a DMF solution $(30 \mathrm{~mL}$ ) of 5-(pyridin-4-yl)-2-thienylboronic acid pinacol ester ( $1.0 \mathrm{~g}, 3.5 \mathrm{mmol})$ and 3-bromo-9-butyl-9H-carbazole ${ }^{31}$ $(1.0 \mathrm{~g}, 3.3 \mathrm{mmol})$ under an argon atmosphere was added aqueous $\mathrm{Na}_{2} \mathrm{CO}_{3}(0.74 \mathrm{~g}, 6.6 \mathrm{mmol})$ and $\mathrm{Pd}\left(\mathrm{PPh}_{3}\right)_{4}(0.09 \mathrm{~g}, 0.1 \mathrm{mmol})$, which was then stirred for $6 \mathrm{~h}$ at $90^{\circ} \mathrm{C}$. After concentrating under reduced pressure, the resulting residue was dissolved in chloroform and washed with water. The chloroform extract was evaporated under reduced pressure. The residue was chromatographed on 
silica gel (chloroform as eluent) to give 1 (1.0 g, yield 78\%) as a yellow solid; m.p. 150-152 ${ }^{\circ} \mathrm{C}$; IR (ATR): $\tilde{\nu}=1590,1445$, $1206 \mathrm{~cm}^{-1} ;{ }^{1} \mathrm{H}$ NMR (400 MHz, acetone- $\left.\mathrm{d}_{6}\right) \delta=0.94(\mathrm{t}, J=$ $7.6 \mathrm{~Hz}, 3 \mathrm{H}), 1.40-1.43(\mathrm{~m}, 2 \mathrm{H}), 1.86-1.90(\mathrm{~m}, 2 \mathrm{H}), 4.47$ $(\mathrm{t}, J=6.8 \mathrm{~Hz}, 2 \mathrm{H}), 7.22-7.27(\mathrm{~m}, 1 \mathrm{H}), 7.47-7.51(\mathrm{~m}, 1 \mathrm{H}), 7.56$ $(\mathrm{d}, J=4.0 \mathrm{~Hz}, 1 \mathrm{H}), 7.60(\mathrm{~d}, J=8.2 \mathrm{~Hz}, 1 \mathrm{H}), 7.64-7.67(\mathrm{~m}, 3 \mathrm{H})$, $7.76(\mathrm{~d}, J=3.8 \mathrm{~Hz}, 1 \mathrm{H}), 7.85(\mathrm{dd}, J=1.9$ and $8.6 \mathrm{~Hz}, 1 \mathrm{H}), 8.25$ $(\mathrm{d}, J=7.4 \mathrm{~Hz}, 1 \mathrm{H}), 8.54(\mathrm{~d}, J=1.3 \mathrm{~Hz}, 1 \mathrm{H}), 8.58(\mathrm{dd}, J=1.7$ and $4.4 \mathrm{~Hz}, 2 \mathrm{H})$ ppm; HRMS (ESI): $m / z(\%):\left[\mathrm{M}+\mathrm{H}^{+}\right]$calcd for $\mathrm{C}_{25} \mathrm{H}_{23} \mathrm{~N}_{2} \mathrm{~S}$, 383.15765; found 383.15845.

3-Bromo-9-butyl-6-(5-(pyridin-4-yl)thiophen-2-yl)-9H-carbazole (2). A solution of $1(0.06 \mathrm{~g}, 0.16 \mathrm{mmol})$ and $N$-bromosuccinimide $(0.034 \mathrm{~g}, 0.19 \mathrm{mmol})$ in dichloromethane $(5 \mathrm{ml})$ was stirred at $0{ }^{\circ} \mathrm{C}$ in dark conditions. After $12 \mathrm{~h}, \mathrm{Na}_{2} \mathrm{~S}_{2} \mathrm{O}_{3}$ aq. was added to the reaction mixture. The organic extract was concentrated under reduced pressure. The residue was dissolved in toluene, and recycling gel permeation chromatography (GPC) was performed to give 2 (0.024 g, yield 33\%) as a yellow solid; m.p. 171-172 ${ }^{\circ} \mathrm{C}$; IR (ATR): $\tilde{\nu}=1590,1453,1214 \mathrm{~cm}^{-1} ;{ }^{1} \mathrm{H}$ NMR $\left(400 \mathrm{MHz}\right.$, acetone-d $\left.\mathrm{d}_{6}\right) \delta=0.93$ $(\mathrm{t}, J=7.6 \mathrm{~Hz}, 3 \mathrm{H}), 1.34-1.40(\mathrm{~m}, 2 \mathrm{H}), 1.79-1.85(\mathrm{~m}, 2 \mathrm{H}), 4.27(\mathrm{t}$, $J=7.2 \mathrm{~Hz}, 2 \mathrm{H}), 7.27$ (d, $J=8.6 \mathrm{~Hz}, 1 \mathrm{H}), 7.33$ (d, $J=3.8 \mathrm{~Hz}, 1 \mathrm{H}), 7.39$ $(\mathrm{d}, J=8.6 \mathrm{~Hz}, 1 \mathrm{H}), 7.47-7.51(\mathrm{~m}, 3 \mathrm{H}), 7.54(\mathrm{dd}, J=1.9$ and $8.6 \mathrm{~Hz}$, $1 \mathrm{H}), 7.74(\mathrm{dd}, J=1.9$ and $8.6 \mathrm{~Hz}, 1 \mathrm{H}), 8.23(\mathrm{~d}, J=1.7 \mathrm{~Hz}, 1 \mathrm{H}), 8.26$ (d, $J=1.4 \mathrm{~Hz}, 1 \mathrm{H}), 8.58$ (d, $J=4.4 \mathrm{~Hz}, 2 \mathrm{H}) \mathrm{ppm}$; HRMS (ESI): $m / z(\%):$ $\left[\mathrm{M}+\mathrm{H}^{+}\right]$calcd for $\mathrm{C}_{25} \mathrm{H}_{32} \mathrm{~N}_{2} \mathrm{BrS}$, 461.06816; found 461.06839 .

3-(5-(3,4-Bis(methoxymethoxy)phenyl)thiophen-2-yl)-9-butyl6-(5-(pyridin-4-yl)thiophen-2-yl)-9H-carbazole (3). To a DMF solution (10 mL) of (5-(3,4-bis(methoxymethoxy)phenyl)thiophen-2-yl)boronic acid pinacol ester $(0.45 \mathrm{~g}, 1.3 \mathrm{mmol})$ and $2(0.55 \mathrm{~g}, 1.2 \mathrm{mmol})$ under an argon atmosphere was added aqueous $\mathrm{Na}_{2} \mathrm{CO}_{3}(0.26 \mathrm{~g}, 2.4 \mathrm{mmol})$ and $\mathrm{Pd}\left(\mathrm{PPh}_{3}\right)_{4}(0.28 \mathrm{~g}, 0.24 \mathrm{mmol})$, followed by stirring for $6 \mathrm{~h}$ at $90{ }^{\circ} \mathrm{C}$. After concentrating under reduced pressure, the resulting residue was dissolved in chloroform and washed with water. The chloroform extract was evaporated under reduced pressure. The residue was chromatographed on silica gel (chloroform as eluent) and then recycling GPC (toluene as eluent) was performed to give 3 ( $0.25 \mathrm{~g}$, yield $32 \%$ ) as a reddish brown viscous solid; m.p. $66-67{ }^{\circ} \mathrm{C}$; IR (ATR): $\tilde{\nu}=1590,1483,1241,1071 \mathrm{~cm}^{-1}$; ${ }^{1} \mathrm{H}$ NMR (400 MHz, acetone- $\left.\mathrm{d}_{6}\right) \delta=0.95(\mathrm{t}, J=7.6 \mathrm{~Hz}, 3 \mathrm{H}), 1.39-1.48(\mathrm{~m}, 2 \mathrm{H}), 1.87-1.95$ $(\mathrm{m}, 2 \mathrm{H}), 3.49(\mathrm{~s}, 3 \mathrm{H}), 3.53(\mathrm{~s}, 3 \mathrm{H}), 4.50(\mathrm{t}, J=7.5 \mathrm{~Hz}, 2 \mathrm{H}), 5.24(\mathrm{~s}, 2 \mathrm{H})$, $5.30(\mathrm{~s}, 2 \mathrm{H}), 7.19(\mathrm{~d}, J=8.4 \mathrm{~Hz}, 1 \mathrm{H}), 7.33(\mathrm{dd}, J=2.2$ and $8.4 \mathrm{~Hz}, 1 \mathrm{H})$, $7.38(\mathrm{~d}, J=4.0 \mathrm{~Hz}, 1 \mathrm{H}), 7.47-7.49(\mathrm{~m}, 2 \mathrm{H}), 7.60(\mathrm{~d}, J=3.8 \mathrm{~Hz}, 1 \mathrm{H})$, 7.65-7.69 (m, 4H), 7.78 (d, $J=3.8 \mathrm{~Hz}, 1 \mathrm{H}), 7.84-7.89(\mathrm{~m}, 2 \mathrm{H}), 8.58$ (dd, $J=1.6$ and $4.4 \mathrm{~Hz}, 2 \mathrm{H}), 8.61(\mathrm{~d}, J=1.2 \mathrm{~Hz}, 1 \mathrm{H}), 8.68(\mathrm{~d}, J=1.4 \mathrm{~Hz}$, 1H) ppm; HRMS (ESI): $m / z(\%):\left[\mathrm{M}+\mathrm{H}^{+}\right]$calcd for $\mathrm{C}_{39} \mathrm{H}_{37} \mathrm{O}_{4} \mathrm{~N}_{2} \mathrm{~S}_{2}$, 661.21893; found 661.21930.

4-(5-(9-Butyl-6-(5-(pyridin-4-yl)thiophen-2-yl)-9H-carbazol-3yl)thiophen-2-yl)benzene-1,2-diol (OF-Py-Cat). To compound 3 $(0.10 \mathrm{~g}, 0.15 \mathrm{mmol})$ was added THF $(3 \mathrm{ml})$ and $1 \mathrm{M} \mathrm{HCl}(2 \mathrm{ml})$, followed by stirring at $80{ }^{\circ} \mathrm{C}$. After $3 \mathrm{~h}$, aqueous $\mathrm{Na}_{2} \mathrm{CO}_{3}$ was added to the reaction mixture to neutralize the solution. The resulting solid was filtered to collect OF-Py-Cat $(0.025 \mathrm{~g}$, yield $29 \%$ ) as a red solid; m.p. $183-185{ }^{\circ} \mathrm{C}$; IR (ATR): $\tilde{\nu}=1629$, 1600, $1427 \mathrm{~cm}^{-1} ;{ }^{1} \mathrm{H}$ NMR $\left(400 \mathrm{MHz}\right.$, acetone- $\left.\mathrm{d}_{6}\right) \delta=0.95(\mathrm{t}, J=$ $7.4 \mathrm{~Hz}, 3 \mathrm{H}$ ), 1.39-1.48 (m, 2H), 1.87-1.89 (m, 2H, overlapping peak of residual proton in acetone- $\left.\mathrm{d}_{6}\right), 4.50(\mathrm{t}, J=7.8 \mathrm{~Hz}, 2 \mathrm{H})$, $6.89(\mathrm{~d}, J=8.2 \mathrm{~Hz}, 1 \mathrm{H}), 7.07(\mathrm{dd}, J=2.2$ and $8.2 \mathrm{~Hz}, 1 \mathrm{H}), 7.19$ $(\mathrm{d}, J=2.2 \mathrm{~Hz}, 1 \mathrm{H}), 7.26(\mathrm{~d}, J=3.8 \mathrm{~Hz}, 1 \mathrm{H}), 7.43(\mathrm{~d}, J=3.8 \mathrm{~Hz}, 1 \mathrm{H})$, $7.60(\mathrm{~d}, J=3.8 \mathrm{~Hz}, 1 \mathrm{H}), 7.64-7.69(\mathrm{~m}, 4 \mathrm{H}), 7.78(\mathrm{~d}, J=3.8 \mathrm{~Hz}, 1 \mathrm{H})$, $7.83(\mathrm{dd}, J=1.9$ and $8.6 \mathrm{~Hz}, 1 \mathrm{H}), 7.87(\mathrm{dd}, J=1.9$ and $8.6 \mathrm{~Hz}, 1 \mathrm{H})$, 8.58-8.59 (m, 3H), 8.67 (d, $J=1.6 \mathrm{~Hz}, 1 \mathrm{H})$ ppm; HRMS (ESI): $m / z$ (\%): $\left[\mathrm{M}+\mathrm{H}^{+}\right]$calcd for $\mathrm{C}_{35} \mathrm{H}_{29} \mathrm{O}_{2} \mathrm{~N}_{2} \mathrm{~S}_{2}, 573.16650$; found 573.16656.

Ethyl 4-(5-(9-butyl-9H-carbazol-3-yl)thiophen-2-yl)benzoate (4). To a DMF solution (20 mL) of ethyl 4-(5-bromothiophen-2yl)benzoate ${ }^{34}$ (0.85 g, $\left.2.7 \mathrm{mmol}\right)$ and (9-butyl-9H-carbazol-3yl)boronic acid pinacol ester ${ }^{32}(0.95 \mathrm{~g}, 2.7 \mathrm{mmol})$ under an argon atmosphere was added aqueous $\mathrm{Na}_{2} \mathrm{CO}_{3}(0.58 \mathrm{~g}, 5.4 \mathrm{mmol})$ and $\mathrm{Pd}\left(\mathrm{PPh}_{3}\right)_{4}(0.09 \mathrm{~g}, 0.1 \mathrm{mmol})$, followed by stirring for $12 \mathrm{~h}$ at $90{ }^{\circ} \mathrm{C}$. After concentrating under reduced pressure, the resulting residue was dissolved in chloroform and then washed with water. The chloroform extract was evaporated under reduced pressure. The residue was chromatographed on silica gel (dichloromethane as eluent) to give 4 (1.07 g, yield $87 \%)$ as a yellow solid; m.p. 116-118 ${ }^{\circ} \mathrm{C}$; IR (ATR): $\tilde{\nu}=1710,1595,1443,1275 \mathrm{~cm}^{-1} ;{ }^{1} \mathrm{H}$ NMR (400 MHz, acetone- $\left.\mathrm{d}_{6}\right) \delta=0.94(\mathrm{t}, J=7.2 \mathrm{~Hz}, 3 \mathrm{H}), 1.36-1.45$ $(\mathrm{m}, 5 \mathrm{H}), 1.86-1.90(\mathrm{~m}, 2 \mathrm{H}), 4.36(\mathrm{q}, J=7.2 \mathrm{~Hz}, 2 \mathrm{H}), 4.47$ $(\mathrm{t}, J=7.2 \mathrm{~Hz}, 2 \mathrm{H}), 7.22-7.26(\mathrm{~m}, 1 \mathrm{H}), 7.47-7.51(\mathrm{~m}, 1 \mathrm{H}), 7.54$ $(\mathrm{d}, J=3.8 \mathrm{~Hz}, 1 \mathrm{H}), 7.61(\mathrm{~d}, J=8.3 \mathrm{~Hz}, 1 \mathrm{H}), 7.64-7.66(\mathrm{~m}, 2 \mathrm{H})$, $7.83-7.86(\mathrm{~m}, 3 \mathrm{H}), 8.05(\mathrm{dd}, J=2.0$ and $6.7 \mathrm{~Hz}, 2 \mathrm{H}), 8.25(\mathrm{~d}, J=$ $7.5 \mathrm{~Hz}, 1 \mathrm{H}$ ), 8.53 (d, $J=1.3 \mathrm{~Hz}, 1 \mathrm{H}$ ) ppm; HRMS (ESI): $m / z(\%):$ $\left[\mathrm{M}+\mathrm{H}^{+}\right]$calcd for $\mathrm{C}_{29} \mathrm{H}_{28} \mathrm{O}_{2} \mathrm{NS}$, 454.18353; found 454.18335.

Ethyl 4-(5-(6-bromo-9-butyl-9H-carbazol-3-yl)thiophen-2-yl)benzoate (5). A solution of $4(0.5 \mathrm{~g}, 1.1 \mathrm{mmol})$ and $N$-bromosuccinimide $(0.195 \mathrm{~g}, 1.1 \mathrm{mmol})$ in dichloromethane $(10 \mathrm{ml})$ was stirred at $0{ }^{\circ} \mathrm{C}$ in dark conditions. After $12 \mathrm{~h}, \mathrm{Na}_{2} \mathrm{~S}_{2} \mathrm{O}_{3}$ aq. was added to the reaction mixture. The organic extract was concentrated under reduced pressure. The residue was dissolved in toluene, and recycling GPC was performed to give 5 (0.12 g, yield 20\%) as a yellow solid; m.p. $158-159{ }^{\circ} \mathrm{C}$; IR (ATR): $\tilde{\nu}=1701,1604,1454,1274 \mathrm{~cm}^{-1} ;{ }^{1} \mathrm{H}$ NMR $(400 \mathrm{MHz}$, dichloromethane- $\left.\mathrm{d}_{2}\right) \delta=0.95(\mathrm{t}, J=7.2 \mathrm{~Hz}, 3 \mathrm{H}), 1.35-1.42$ $(\mathrm{m}, 5 \mathrm{H}), 1.81-1.88(\mathrm{~m}, 2 \mathrm{H}), 4.29(\mathrm{t}, J=7.2 \mathrm{~Hz}, 2 \mathrm{H}), 4.37$ (q, $J=7.2 \mathrm{~Hz}, 2 \mathrm{H}), 7.33(\mathrm{~d}, J=8.6 \mathrm{~Hz}, 1 \mathrm{H}), 7.37(\mathrm{~d}, J=3.8 \mathrm{~Hz}, 1 \mathrm{H})$, $7.44-7.47(\mathrm{~m}, 2 \mathrm{H}), 7.57(\mathrm{dd}, J=2.0$ and $8.6 \mathrm{~Hz}, 1 \mathrm{H}), 7.71-7.74$ $(\mathrm{m}, 2 \mathrm{H}), 7.79$ (dd, $J=1.9$ and $8.4 \mathrm{~Hz}, 1 \mathrm{H}), 8.03-8.06(\mathrm{~m}, 2 \mathrm{H})$, 8.25 (d, $J=2.4 \mathrm{~Hz}, 1 \mathrm{H}), 8.31$ (d, $J=1.8 \mathrm{~Hz}, 1 \mathrm{H})$ ppm; HRMS (APCI): $m / z$ (\%): $\left[\mathrm{M}^{+}\right.$] calcd for $\mathrm{C}_{29} \mathrm{H}_{26} \mathrm{O}_{2} \mathrm{NBrS}, 531.08621$; found 531.08643 .

Ethyl 4-(5-(9-butyl-6-(5-(pyridin-4-yl)thiophen-2-yl)-9H-carbazol3-yl)thiophen-2-yl)benzoate (6). To a DMF solution (3 mL) of 5-(pyridin-4-yl)-2-thienylboronic acid pinacol ester $(0.065 \mathrm{~g}$, $0.23 \mathrm{mmol}$ ) and $5(0.11 \mathrm{~g}, 0.21 \mathrm{mmol})$ under an argon atmosphere was added aqueous $\mathrm{Na}_{2} \mathrm{CO}_{3}(0.044 \mathrm{~g}, 0.41 \mathrm{mmol})$ and $\mathrm{Pd}\left(\mathrm{PPh}_{3}\right)_{4}(0.007 \mathrm{~g}, 0.006 \mathrm{mmol})$, followed by stirring for $6 \mathrm{~h}$ at $90{ }^{\circ} \mathrm{C}$. After concentrating under reduced pressure, the resulting residue was dissolved in chloroform and washed with water. The chloroform extract was evaporated under reduced pressure. The residue was chromatographed on silica gel (chloroform as eluent) to give $6(0.1 \mathrm{~g}$, yield $82 \%)$ as an orange yellow solid; m.p. 207-208 ${ }^{\circ}$ C; IR (ATR): $\tilde{\nu}=1710,1590,1440,1271 \mathrm{~cm}^{-1}$; ${ }^{1} \mathrm{H}$ NMR (400 MHz, dichloromethane- $\left.\mathrm{d}_{2}\right) \delta=0.95(\mathrm{t}, J=7.3 \mathrm{~Hz}, 3 \mathrm{H})$, 
1.38-1.45 (m, 5H), 1.86-1.93 (m, 2H), 4.33-4.40 (m, 4H), 7.42 $(\mathrm{d}, J=3.7 \mathrm{~Hz}, 1 \mathrm{H}), 7.43(\mathrm{~d}, J=3.8 \mathrm{~Hz}, 1 \mathrm{H}), 7.47-7.50(\mathrm{~m}, 2 \mathrm{H})$, $7.53-7.54(\mathrm{~m}, 2 \mathrm{H}), 7.58(\mathrm{~d}, J=3.8 \mathrm{~Hz}, 1 \mathrm{H}), 7.71-7.76(\mathrm{~m}, 3 \mathrm{H})$, 7.80-7.83 (m, 2H), 8.05-8.07 (m, 2H), 8.43-8.44 (m, 2H), 8.58 (d, $J=4.6 \mathrm{~Hz}, 2 \mathrm{H}$ ) ppm; HRMS (ESI): $m / z(\%):\left[\mathrm{M}+\mathrm{H}^{+}\right]$calcd for $\mathrm{C}_{38} \mathrm{H}_{33} \mathrm{O}_{2} \mathrm{~N}_{2} \mathrm{~S}_{2}, 613.19780$; found 613.19824.

4-(5-(9-Butyl-6-(5-(pyridin-4-yl)thiophen-2-yl)-9H-carbazol-3yl)thiophen-2-yl)benzoic acid (OF-Py-Car). To a solution of 6 $(0.035 \mathrm{~g}, 0.06 \mathrm{mmol})$ in a mixed solvent of ethanol $(14 \mathrm{ml})$ and dichloromethane $(5 \mathrm{ml})$ was added dropwise aqueous $\mathrm{NaOH}$ $(5 \mathrm{ml}, 0.05 \mathrm{M})$ with stirring at $75{ }^{\circ} \mathrm{C}$. After further stirring for $12 \mathrm{~h}$, the solution was concentrated under reduced pressure. The residue was dissolved in dichloromethane, and washed with water, in which the aqueous layer was acidified to $\mathrm{pH} 2$ with $2 \mathrm{M} \mathrm{HCl}$. The resulting solid was filtered to collect OF-Py-Car $(0.027 \mathrm{~g}$, yield $81 \%)$ as an orange solid; m.p. over $300{ }^{\circ} \mathrm{C}$; IR (ATR): $\tilde{\nu}=1695,1601,1448,1288 \mathrm{~cm}^{-1} ;{ }^{1} \mathrm{H}$ NMR $\left(500 \mathrm{MHz}\right.$, tetrahydrofuran- $\left.\mathrm{d}_{8}\right) \delta=0.96(\mathrm{t}, J=7.0 \mathrm{~Hz}, 3 \mathrm{H}), 1.39-$ $1.44(\mathrm{~m}, 2 \mathrm{H}), 1.55-1.88(\mathrm{~m}, 2 \mathrm{H}$, overlapping peak of residual proton in tetrahydrofuran- $\left.\mathrm{d}_{8}\right), 4.44(\mathrm{t}, J=7.0 \mathrm{~Hz}, 2 \mathrm{H}), 7.48$ $(\mathrm{d}, J=3.9 \mathrm{~Hz}, 1 \mathrm{H}), 7.51(\mathrm{~d}, J=3.9 \mathrm{~Hz}, 1 \mathrm{H}), 7.56-7.58(\mathrm{~m}, 4 \mathrm{H})$, $7.68(\mathrm{~d}, J=4.0 \mathrm{~Hz}, 1 \mathrm{H}), 7.74-7.79(\mathrm{~m}, 3 \mathrm{H}), 7.81-7.84(\mathrm{~m}, 2 \mathrm{H})$, 8.03-8.05 (m, 2H), 8.54-8.56 (m, 4H) ppm; HRMS (ESI): $m / z(\%)$ : $\left[\mathrm{M}+\mathrm{H}^{+}\right]$calcd for $\mathrm{C}_{36} \mathrm{H}_{29} \mathrm{O}_{2} \mathrm{~N}_{2} \mathrm{~S}_{2}, 585.16650$; found 585.16685.

9-Butyl-3,6-di(thiophen-2-yl)-9H-carbazole (7) ${ }^{32}$. A solution of 3,6-dibromo-9-butyl-9H-carbazole (3.8 g, $10.0 \mathrm{mmol}$ ), 2-thienylboronic acid $(2.5 \mathrm{~g}, 25.0 \mathrm{mmol})$, aqueous $\mathrm{Na}_{2} \mathrm{CO}_{3}(2.5 \mathrm{~g}$, $20.0 \mathrm{mmol})$ and $\mathrm{Pd}\left(\mathrm{PPh}_{3}\right)_{4}(0.61 \mathrm{~g}, 0.5 \mathrm{mmol})$ in $\mathrm{DMF}(40 \mathrm{ml})$ was stirred for $7 \mathrm{~h}$ at $80{ }^{\circ} \mathrm{C}$. After concentrating under reduced pressure, the resulting residue was dissolved in dichloromethane and washed with water. The dichloromethane extract was evaporated under reduced pressure. The residue was chromatographed on silica gel (dichloromethane: hexane $1: 1$ as the eluent) to give 7 (1.6 g, yield $40 \%$ ) as a white solid; ${ }^{1} \mathrm{H}$ NMR (400 MHz, acetone- $\left.\mathrm{d}_{6}\right) \delta=0.94(\mathrm{t}, J=7.2 \mathrm{~Hz}, 3 \mathrm{H}), 1.39-1.45$ $(\mathrm{m}, 2 \mathrm{H}), 1.85-1.93(\mathrm{~m}, 2 \mathrm{H}), 4.47(\mathrm{t}, J=7.2 \mathrm{~Hz}, 2 \mathrm{H}), 7.13$ (dd, $J=3.5$ and $5.1 \mathrm{~Hz}, 2 \mathrm{H}), 7.39$ (dd, $J=1.2$ and $5.1 \mathrm{~Hz}, 2 \mathrm{H}$ ), $7.48(\mathrm{~d}, J=1.2$ and $3.5 \mathrm{~Hz}, 2 \mathrm{H}), 7.62(\mathrm{~d}, J=8.6 \mathrm{~Hz}, 2 \mathrm{H}), 7.79$ (dd, $J=1.9$ and $8.6 \mathrm{~Hz}, 2 \mathrm{H}), 8.56(\mathrm{~d}, J=1.4 \mathrm{~Hz}, 2 \mathrm{H}) \mathrm{ppm}$.

3,6-Bis(5-bromothiophen-2-yl)-9-butyl-9H-carbazole (8). A solution of 7 ( $3.8 \mathrm{~g}, 10.0 \mathrm{mmol})$ and $N$-bromosuccinimide $(3.7 \mathrm{~g}, 20.0 \mathrm{mmol})$ in chloroform $(200 \mathrm{ml})$ was stirred at $0{ }^{\circ} \mathrm{C}$ in dark conditions. After $2 \mathrm{~h}, \mathrm{Na}_{2} \mathrm{~S}_{2} \mathrm{O}_{3}$ aq. was added to the reaction mixture. The organic extract was concentrated under reduced pressure. The residue was compound $8(5.3 \mathrm{~g}$, yield $95 \%)$ as a yellow solid; m.p. $150-152{ }^{\circ} \mathrm{C}$; IR (ATR): $\tilde{\nu}=1601,1482,1430 \mathrm{~cm}^{-1} ;{ }^{1} \mathrm{H}$ NMR (400 MHz, acetone- $\left.\mathrm{d}_{6}\right) \delta=0.93(\mathrm{t}, J=7.3 \mathrm{~Hz}, 3 \mathrm{H}), 1.37-1.44$ (m, 2H), 1.84-1.90 (m, 2H), $4.47(\mathrm{t}, J=7.2 \mathrm{~Hz}, 2 \mathrm{H}), 7.18$ (d, $J=3.9 \mathrm{~Hz}, 2 \mathrm{H}), 7.30(\mathrm{~d}, J=3.9 \mathrm{~Hz}, 2 \mathrm{H}), 7.64(\mathrm{~d}, J=8.4 \mathrm{~Hz}, 2 \mathrm{H})$, $7.74(\mathrm{dd}, J=1.8$ and $8.4 \mathrm{~Hz}, 2 \mathrm{H}), 8.52(\mathrm{~d}, J=1.3 \mathrm{~Hz}, 2 \mathrm{H}) \mathrm{ppm}$; HRMS (APCI): $m / z(\%):\left[\mathrm{M}+\mathrm{H}^{+}\right]$calcd for $\mathrm{C}_{24} \mathrm{H}_{20} \mathrm{NBr}_{2} \mathrm{~S}_{2}$, 545.93780; found 545.93811 .

Diethyl 4,4'-((9-butyl-9H-carbazole-3,6-diyl)bis(thiophene-5,2diyl))dibenzoate (9). A solution of 8 (1.0 g, $1.8 \mathrm{mmol})$, 4-ethoxycarbonylphenylboronic acid (0.9 g, $4.5 \mathrm{mmol})$, aqueous $\mathrm{Na}_{2} \mathrm{CO}_{3}$ $(0.4 \mathrm{~g}, 3.6 \mathrm{mmol})$ and $\mathrm{Pd}\left(\mathrm{PPh}_{3}\right)_{4}(0.11 \mathrm{~g}, 0.09 \mathrm{mmol})$ in $\mathrm{DMF}$
(10 ml) was stirred for $4 \mathrm{~h}$ at $90{ }^{\circ} \mathrm{C}$. After concentrating under reduced pressure, the resulting residue was dissolved in dichloromethane and washed with water. The dichloromethane extract was evaporated under reduced pressure. The residue was chromatographed on silica gel (dichloromethane : hexane $3: 1$ as eluent) to give $9(0.65 \mathrm{~g}$, yield $50 \%)$ as a yellow solid; m.p. 172$174{ }^{\circ} \mathrm{C}$; IR (ATR): $\tilde{\nu}=1705,1601,1444,1270 \mathrm{~cm}^{-1} ;{ }^{1} \mathrm{H}$ NMR (400 MHz, acetone- $\left.\mathrm{d}_{6}\right) \delta=0.96(\mathrm{t}, J=7.6 \mathrm{~Hz}, 3 \mathrm{H}), 1.36-1.47$ $(\mathrm{m}, 8 \mathrm{H}), 1.88-1.93(\mathrm{~m}, 2 \mathrm{H}), 4.36(\mathrm{q}, J=7.2 \mathrm{~Hz}, 4 \mathrm{H}), 4.51$ $(\mathrm{t}, J=7.2 \mathrm{~Hz}, 2 \mathrm{H}), 7.58(\mathrm{~d}, J=3.8 \mathrm{~Hz}, 2 \mathrm{H}), 7.67-7.70(\mathrm{~m}, 4 \mathrm{H})$, 7.85-7.90 (m, 6H), 8.05-8.08 (m, 4H), $8.67(\mathrm{~d}, J=1.3 \mathrm{~Hz}, 2 \mathrm{H})$ ppm; HRMS (APCI): $m / z$ (\%): $\left[\mathrm{M}+\mathrm{H}^{+}\right]$calcd for $\mathrm{C}_{42} \mathrm{H}_{38} \mathrm{O}_{4} \mathrm{NS}_{2}$, 684.22368; found 684.22290.

4,4'-((9-Butyl-9H-carbazole-3,6-diyl)bis(thiophene-5,2-diyl))dibenzoic acid (OF-Car-Car). To a solution of $9(0.1 \mathrm{~g}, 0.15 \mathrm{mmol})$ in a mixed solvent of ethanol $(100 \mathrm{ml})$ and dichloromethane (30 ml) was added dropwise aqueous $\mathrm{NaOH}(32 \mathrm{ml}, 0.05 \mathrm{M})$ with stirring at $75{ }^{\circ} \mathrm{C}$. After further stirring for $12 \mathrm{~h}$, the solution was concentrated under reduced pressure. The residue was dissolved in dichloromethane and washed with water, in which the aqueous layer was acidified to $\mathrm{pH} 1$ with $2 \mathrm{M} \mathrm{HCl}$. The resulting solid was filtered to collect OF-Car-Car $(0.08 \mathrm{~g}$, yield $89 \%)$ as a yellow solid; m.p. over $300{ }^{\circ} \mathrm{C}$; IR (ATR): $\tilde{\nu}=1678,1601,1425$, $1292 \mathrm{~cm}^{-1} ;{ }^{1} \mathrm{H}$ NMR (400 MHz, tetrahydrofuran-d $\left.{ }_{8}\right) \delta=0.96$ $(\mathrm{t}, J=7.5 \mathrm{~Hz}, 3 \mathrm{H}), 1.36-1.48$ (m, 2H), 1.56-1.89 (m, 2H, overlapping peak of residual proton in tetrahydrofuran- $\left.\mathrm{d}_{8}\right), 4.43$ $(\mathrm{t}, J=7.0 \mathrm{~Hz}, 2 \mathrm{H}), 7.48(\mathrm{~d}, J=3.5 \mathrm{~Hz}, 2 \mathrm{H}), 7.56-7.58(\mathrm{~m}, 4 \mathrm{H})$, $7.78-7.83(\mathrm{~m}, 6 \mathrm{H}), 8.04(\mathrm{~d}, J=8.5 \mathrm{~Hz}, 4 \mathrm{H}), 8.55(\mathrm{~d}, J=1.5 \mathrm{~Hz}$, $2 \mathrm{H}) \mathrm{ppm} ;{ }^{13} \mathrm{C}$ NMR (125 MHz, tetrahydrofuran-d $\left.\mathrm{d}_{8}\right) \delta=14.03$, $21.09,31.96,43.01,110.29,118.26,123.89,124.13,124.76$, 125.29, 126.42, 127.65, 130.07, 130.90, 131.07, 139.24, 141.59,

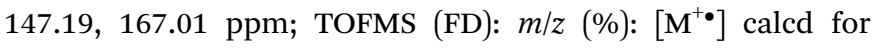
$\mathrm{C}_{38} \mathrm{H}_{29} \mathrm{O}_{4} \mathrm{NS}_{2}$, 627.15380; found 627.15430.

3,6-Bis(5-(3,4-bis(methoxymethoxy)phenyl)thiophen-2-yl)-9butyl-9H-carbazole (10). A solution of $8(0.2 \mathrm{~g}, 0.37 \mathrm{mmol})$, (3,4-bis(methoxymethoxy)phenyl)boronic acid pinacol ester (0.3 g, $0.9 \mathrm{mmol})$, aqueous $\mathrm{Na}_{2} \mathrm{CO}_{3}(0.08 \mathrm{~g}, 0.7 \mathrm{mmol})$ and $\mathrm{Pd}\left(\mathrm{PPh}_{3}\right)_{4}(0.02 \mathrm{~g}, 0.02 \mathrm{mmol})$ in $\mathrm{DMF}(3 \mathrm{ml})$ was stirred for $4 \mathrm{~h}$ at $90{ }^{\circ} \mathrm{C}$. After concentrating under reduced pressure, the resulting residue was dissolved in dichloromethane and washed with water. The dichloromethane extract was evaporated under reduced pressure. The residue was chromatographed on silica gel (ethyl acetate: hexane 1:1 as eluent) and then recycling GPC (toluene as eluent) was performed to give 10 (0.15 g, yield 52\%) as a yellow solid; m.p. $41-43{ }^{\circ} \mathrm{C}$; IR (ATR): $\tilde{\nu}=1600,1484,1241$, 1151, $1071 \mathrm{~cm}^{-1} ;{ }^{1} \mathrm{H}$ NMR (400 MHz, acetone-d $\left.\mathrm{d}_{6}\right) \delta=0.82$ $(\mathrm{t}, J=7.2 \mathrm{~Hz}, 3 \mathrm{H}), 1.23-1.29(\mathrm{~m}, 2 \mathrm{H}), 1.70-1.75(\mathrm{~m}, 2 \mathrm{H}), 3.48$ $(\mathrm{s}, 6 \mathrm{H}), 3.51(\mathrm{~s}, 6 \mathrm{H}), 4.23(\mathrm{t}, J=7.8 \mathrm{~Hz}, 2 \mathrm{H}), 5.21(\mathrm{~s}, 4 \mathrm{H}), 5.28(\mathrm{~s}$, $4 \mathrm{H}), 7.14(\mathrm{~d}, J=8.4 \mathrm{~Hz}, 2 \mathrm{H}), 7.25-7.29(\mathrm{~m}, 4 \mathrm{H}), 7.37$ (d, $J=3.7 \mathrm{~Hz}$, $2 \mathrm{H}), 7.41$ (d, $J=8.6 \mathrm{~Hz}, 2 \mathrm{H}), 7.48$ (d, $J=2.2 \mathrm{~Hz}, 2 \mathrm{H}), 7.70$ (dd, $J=1.8$ and $8.6 \mathrm{~Hz}, 2 \mathrm{H}), 8.53(\mathrm{~d}, J=1.8 \mathrm{~Hz}, 2 \mathrm{H})$ ppm; HRMS (ESI): $m / z(\%):\left[\mathrm{M}+\mathrm{Na}^{+}\right]$calcd for $\mathrm{C}_{44} \mathrm{H}_{45} \mathrm{O}_{8} \mathrm{NS}_{2} \mathrm{Na}$, 802.24788; found 802.24664 .

4,4'-((9-Butyl-9H-carbazole-3,6-diyl)bis(thiophene-5,2-diyl))bis(benzene-1,2-diol) (OF-Cat-Cat). To compound 10 (0.15 g, $0.19 \mathrm{mmol})$ was added THF ( $3 \mathrm{ml})$ and $1 \mathrm{M} \mathrm{HCl}(2 \mathrm{ml})$, followed 
by stirring at $80{ }^{\circ} \mathrm{C}$ for $12 \mathrm{~h}$. After concentrating under reduced pressure, the resulting residue was subjected to reprecipitation to afford OF-Cat-Cat (0.1 g, yield $91 \%)$ as a dark green solid; m.p. over $300{ }^{\circ} \mathrm{C}$; IR (ATR): $\tilde{\nu}=1651,1599,1486 \mathrm{~cm}^{-1} ;{ }^{1} \mathrm{H}$ NMR $\left(500 \mathrm{MHz}\right.$, acetonitrile- $\left.\mathrm{d}_{3}\right) \delta=0.94(\mathrm{t}, J=7.5 \mathrm{~Hz}, 3 \mathrm{H}), 1.36-1.41$ $(\mathrm{m}, 2 \mathrm{H}), 1.79-2.00(\mathrm{~m}, 2 \mathrm{H}$, overlapping peak of residual proton in acetonitrile- $\left.\mathrm{d}_{3}\right), 4.39(\mathrm{t}, J=7.0 \mathrm{~Hz}, 2 \mathrm{H}), 6.87(\mathrm{~d}, J=8.0 \mathrm{~Hz}$, $2 \mathrm{H}$ ), 7.09 (dd, $J=2.5$ and $8.0 \mathrm{~Hz}, 2 \mathrm{H}), 7.17$ (d, $J=2.5 \mathrm{~Hz}, 2 \mathrm{H})$, $7.26(\mathrm{~d}, J=3.5 \mathrm{~Hz}, 2 \mathrm{H}), 7.39(\mathrm{~d}, J=3.5 \mathrm{~Hz}, 2 \mathrm{H}), 7.57(\mathrm{~d}, J=$ $8.5 \mathrm{~Hz}, 2 \mathrm{H}), 7.80(\mathrm{dd}, J=1.5$ and $8.5 \mathrm{~Hz}, 2 \mathrm{H}), 8.49(\mathrm{~d}, J=2.0 \mathrm{~Hz}$, $2 \mathrm{H})$ ppm; TOFMS (FD): $m / z(\%):\left[\mathrm{M}^{+}\right.$] calcd for $\mathrm{C}_{36} \mathrm{H}_{29} \mathrm{O}_{4} \mathrm{NS}_{2}$, 603.15380; found 603.15521.

\section{Preparation of DSSCs}

The $\mathrm{TiO}_{2}$ paste (JGC Catalysts and Chemicals Ltd, PST-18NR) was deposited on a fluorine-doped-tin-oxide (FTO) substrate by doctor-blading, and sintered for $50 \mathrm{~min}$ at $450{ }^{\circ} \mathrm{C}$. The $9 \mu \mathrm{m}$ thick $\mathrm{TiO}_{2}$ electrode was immersed into $0.1 \mathrm{mM}$ dye solution in THF for 15 hours, which was enough to adsorb the dye sensitizers. The DSSCs were fabricated by using the $\mathrm{TiO}_{2}$ electrode $\left(0.5 \times 0.5 \mathrm{~cm}^{2}\right.$ in the photoactive area) thus prepared, Pt-coated glass as the counter electrode, and a solution of $0.05 \mathrm{M}$ iodine, 0.1 M lithium iodide, and 0.6 M 1,2-dimethyl3-propylimidazolium iodide in acetonitrile as the electrolyte. The photocurrent-voltage characteristics were measured using a potentiostat under simulated solar light (AM 1.5, $100 \mathrm{~mW} \mathrm{~cm}^{-2}$ ). IPCE spectra were measured under monochromatic irradiation with a tungsten-halogen lamp and a monochromator. The amount of dye molecules adsorbed on $\mathrm{TiO}_{2}$ film was determined from the calibration curve by absorption spectral measurement of the concentration change of the dye solution before and after adsorption. The quantification of dye was made based on the molar extinction coefficient for $\lambda_{\max }^{\text {abs }}$ of dye in the above solution. Absorption spectra of the dyes adsorbed on $\mathrm{TiO}_{2}$ film were recorded on the dyes-adsorbed $\mathrm{TiO}_{2}$ film in the transmission mode with a calibrated integrating sphere system.

\section{Acknowledgements}

This work was supported by Grants-in-Aid for Scientific Research (B) from the Japan Society for the Promotion of Science (JSPS) KAKENHI Grant Number 15H03859, by Matching Planner Program (MP27115659061) from the Japan Science and Technology Agency (JST) and by the Yazaki Memorial Foundation for Science and Technology.

\section{Notes and references}

1 B. O'Regan and M. Grätzel, Nature, 1991, 353, 737.

2 A. Mishra, M. K. R. Fischer and P. Bäuerle, Angew. Chem., Int. Ed., 2009, 48, 2474.

3 (a) Z. Ning and H. Tian, Chem. Commun., 2009, 5483; (b) Z. Ning, Y. Fu and H. Tian, Energy Environ. Sci., 2010, 3, 1170 .
4 (a) Y. Ooyama and Y. Harima, Eur. J. Org. Chem., 2009, 2903;

(b) Y. Ooyama and Y. Harima, ChemPhysChem, 2012, 13, 4032.

5 A. Hagfeldt, G. Boschloo, L. Sun, L. Kloo and H. Pettersson, Chem. Rev., 2010, 110, 6595.

6 N. Manfredi, B. Cecconi and A. Abbotto, Eur. J. Org. Chem., 2014, 7069.

7 L. Zhang and J. M. Cole, ACS Appl. Mater. Interfaces, 2015, 7, 3427.

8 C.-P. Lee, R. Y.-Y. Lin, L.-Y. Lin, C.-T. Li, T.-C. Chu, S.-S. Sun, J. T. Lin and K.-C. Ho, RSC Adv., 2015, 5, 23810.

9 B. Pashaei, H. Shahroosvand, M. Graetzel and M. K. Nazeeruddin, Chem. Rev., 2016, 116, 9485.

10 (a) K.-L. Wu, A. J. Huckaba, J. N. Clifford, Y.-W. Yang, A. Yella and E. Palomares, Inorg. Chem., 2016, 55, 7388; (b) H. Ozawa, T. Sugiura, T. Kuroda, K. Nozawa and H. Arakawa, J. Mater. Chem. A, 2016, 4, 1762.

11 (a) H. Imahori, T. Umeyama and S. Ito, Acc. Chem. Res., 2009, 42, 1809; (b) L.-L. Li and E. W.-G. Diau, Chem. Soc. Rev., 2013, 42, 291; (c) K. Ladomenou, T. N. Kitsopoulos, G. D. Sharma and A. G. Coutsolelos, RSC Adv., 2014, 4, 21379; (d) T. Higashino and H. Imahori, Dalton Trans., 2015, 44, 448.

12 (a) T. Bessho, S. M. Zakeeruddin, C.-Y. Yeh, E. W.-G. Diau and M. Grätzel, Angew. Chem., Int. Ed., 2010, 49, 6646; (b) A. Yella, H.-W. Lee, H. N. Tsao, C. Yi, A. K. Chandiran, M. K. Nazeeruddin, E. W.-G. Diau, C.-Y. Yeh, S. M. Zakeeruddin and M. Grätzel, Science, 2011, 334, 629; (c) S. Mathew, A. Yella, P. Gao, R. Humphry-Baker, B. F. E. Curchod, N. Ashari-Astani, I. Tavernelli, U. Rothlisberger, Md. K. Nazeeruddin and M. Grätzel, Nat. Chem., 2014, 6, 242; (d) A. Yella, C.-L. Mai, S. M. Zakeeruddin, S.-N. Chang, C.H. Hsieh, C.-Y. Yeh and M. Grätzel, Angew. Chem., Int. Ed., 2014, 53, 2973; (e) T. Higashino, Y. Fujimori, K. Sugiura, Y. Tsuji, S. Ito and H. Imahori, Angew. Chem., Int. Ed., 2015, 54, 9052; $(f)$ J. P. Hill, Angew. Chem., Int. Ed., 2016, 55, 2976; $(g)$ F. Lodermeyer, R. D. Costa, J. Malig, N. Jux and D. M. Guldi, Chem. - Eur. J., 2016, 22, 7851; (h) G. Copley, D. Hwang, D. Kim and A. Osuka, Angew. Chem., Int. Ed., 2016, 55, 10287.

13 (a) T. Zhang, X. Qian, P. Zhang, Y.-Z. Zhu and J.-Y. Zheng, Chem. Commun., 2015, 51, 3782; (b) Y. Xie, Y. Tang, W. Wu, Y. Wang, J. Liu, X. Li, H. Tian and W.-H. Zhu, J. Am. Chem. Soc., 2015, 137, 14055; (c) K. Sirithip, N. Prachumrak, R. Rattanawan, T. Keawin, T. Sudyoadsuk, S. Namuangruk, S. Jungsuttiwong and V. Promarak, Chem. - Asian J., 2015, 10, 882; (d) S. Mathew, N. A. Astani, B. F. E. Curchod, J. H. Delcamp, M. Marszalek, J. Frey, U. Rothlisberger, M. K. Nazeeruddina and M. Grätzel, J. Mater. Chem. A, 2016, 4, 2332; (e) L. Zeininger, F. Lodermeyer, R. D. Costa, D. M. Guldi and A. Hirsch, Chem. Commun., 2016, 52, 8842; $(f)$ J. Luo, J. Zhang, K.-W. Huang, Q. Qi, S. Dong, J. Zhang, P. Wang and J. Wu, J. Mater. Chem. A, 2016, 4, 8428; (g) C. Li, L. Luo, D. Wu, R. Jiang, J. Lan, R. Wang, L. Huang, S. Yang and J. You, J. Mater. Chem. A, 2016, 4, 11829; (h) Y.-C. Liu, H.-H. Chou, F.-Y. Ho, H.-J. Wei, T.-C. Wei and C.-Y. Yeh, J. Mater. Chem. A, 2016, 4, 11878.

14 (a) J.-J. Cid, J.-H. Yum, S.-R. Jang, M. K. Nazeeruddin, E. Martínez-Ferrero, E. Palomares, J. Ko, M. Grätzel and 
T. Torres, Angew. Chem., Int. Ed., 2007, 46, 8358; (b) M. Kimura, H. Nomoto, N. Masaki and S. Mori, Angew. Chem., Int. Ed., 2012, 51, 4371; (c) M.-E. Ragoussi, J.-J. Cid, J.-H. Yum, G. De La Torre, D. D. Censo, M. Grätzel, M. K. Nazeeruddin and T. Torres, Angew. Chem., Int. Ed., 2012, 51, 4375; (d) L. Yu, K. Fan, T. Duan, X. Chen, R. Li and T. Peng, ACS Sustainable Chem. Eng., 2014, 2, 718; (e) T. Ikeuchi, H. Nomoto, N. Masaki, M. J. Griffith, S. Mori and M. Kimura, Chem. Commun., 2014, 50, 1941; $(f)$ T. Ikeuchi, S. Agrawal, M. Ezoe, S. Mori and M. Kimura, Chem. - Asian J., 2015, 10, 2347; (g) L. Tejerina, M. V. Martínez-Díaz, M. K. Nazeeruddin and T. Torres, Chem. - Eur. J., 2016, 22, 4369.

15 (a) X. Wang, J. Yang, H. Yu, F. Li, L. Fan, W. Sun, Y. Liu, Z. Y. Koh, J. Pan, W.-L. Yim, L. Yan and Q. Wang, Chem. Commun., 2014, 50, 3965; (b) S.-G. Li, K.-J. Jiang, J.-H. Huang, L.-M. Yang and Y.-L. Song, Chem. Commun., 2014, 50, 4309; (c) D. K. Panda, F. S. Goodson, S. Ray and S. Saha, Chem. Commun., 2014, 50, 5358; (d) K. Kakiage, Y. Aoyama, T. Yano, T. Otsuka, T. Kyomen, M. Unno and M. Hanaya, Chem. Commun., 2014, 50, 6379; (e) A. Amacher, C. Yi, J. Yang, M. P. Bircher, Y. Fu, M. Cascella, M. Grätzel, S. Decurtins and S.-X. Liu, Chem. Commun., 2014, 50, 6540; $(f)$ W.-I. Hung, Y.-Y. Liao, T.-H. Lee, Y.-C. Ting, J.-S. Ni, W.-S. Kao, J. T. Lin, T.-C. Wei and Y.-S. Yen, Chem. Commun., 2015, 51, 2152; ( $g$ ) X. Li, Z. Zheng, W. Jiang, W. Wu, Z. Wang and H. Tian, Chem. Commun., 2015, 51, 3590; $(h)$ K. Kakiage, Y.i Aoyama, T. Yano, K. Oya, T. Kyomen and M. Hanaya, Chem. Commun., 2015, 51, 6315; (i) L. Yang, Z. Zheng, Y. Li, W. Wu, H. Tian and Z. Wang, Chem. Commun., 2015, 51, 4842; $(j)$ N. Shibayama, Y. Inoue, M. Abe, S. Kajiyama, H. Ozawa, H. Miura and H. Arakawa, Chem. Commun., 2015, 51, 12795; (k) K. Kakiage, Y. Aoyama, T. Yano, K. Oya, J. Fujisawa and M. Hanaya, Chem. Commun., 2015, 51, 15894.

16 (a) J.-S. Ni, Y.-C. Yen and J. T. Lin, Chem. Commun., 2015, 51, 17080; (b) Y.-D. Lin, B.-Y. Ke, Y. J. Chang, P.-T. Chou, K.-L. Liau, C.-Y. Liu and T. J. Chow, J. Mater. Chem. A, 2015, 3, 16831; (c) S. S. Soni, K. B. Fadadu, J. V. Vaghasiya, B. G. Solanki, K. K. Sonigara, A. Singh, D. Das and P. K. Iyer, J. Mater. Chem. A, 2015, 3, 21664; (d) X. Li, Y. Hu, I. SanchezMolina, Y. Zhou, F. Yu, S. A. Haque, W. Wu, J. Hua, H. Tian and N. Robertson, J. Mater. Chem. A, 2015, 3, 2173; (e) Y. Hu, A. Ivaturi, M. Planells, C. L. Boldrini, A. O. Biroli and N. Robertson, J. Mater. Chem. A, 2016, 4, 2509; $(f)$ H. Wu, L. Yang, Y. Li, M. Zhang, J. Zhang, Y. Guo and P. Wang, J. Mater. Chem. A, 2016, 4, 519; (g) J. Wu, G. Li, L. Zhang, G. Zhou and Z.-S. Wang, J. Mater. Chem. A, 2016, 4, 3342; (h) J.-S. Ni, Y.-C. Yen and J. T. Lin, J. Mater. Chem. A, 2016, 4, 6553; (i) A. J. Huckaba, A. Yella, P. Brogdon, J. S. Murphy, M. K. Nazeeruddin, M. Grätzel and J. H. Delcamp, Chem. Commun., 2016, 52, 8424; (j) T.-Y. Li, C. Su, S. B. Akula, W.-G. Sun, H.-M. Chien and W.-R. Li, Org. Lett., 2016, 18, 3386; (k) Y. Gao, X. Li, Y. Hu, Y. Fan, J. Yuan, N. Robertson, J. Hua and S. R. Marder, J. Mater. Chem. A, 2016, 4, 12865.

17 (a) Z. Yao, M. Zhang, H. Wu, L. Yang, R. Li and P. Wang, J. Am. Chem. Soc., 2015, 137, 3799; (b) N. Zhou,
K. Prabakaran, B. Lee, S. H. Chang, B. Harutyunyan, P. Guo, M. R. Butler, A. Timalsina, M. J. Bedzyk, M. A. Ratner, S. Vegiraju, S. Yau, C.-G. Wu, R. P. H. Chang, A. Facchetti, M.-C. Chen and T. J. Marks, J. Am. Chem. Soc., 2015, 137, 4414; (c) Y.-S. Yen, J.-S. Ni, T.-Y. Lin, W.-I. Hung, J. T. Lin and M.-C. P. Yeh, Eur. J. Org. Chem., 2015, 7367; (d) H. Jiang, G. Ferrara, X. Zhang, K. Oniwa, A. Islam, L. Han, Y.-J. Sun, M. Bao, N. Asao, Y. Yamamoto and T. Jin, Chem. - Eur. J., 2015, 21, 4065; (e) K. Matsumura, S. Yoshizaki, M. M. Maitani, Y. Wada, Y. Ogomi, S. Hayase, T. Kaiho, S. Fuse, H. Tanaka and T. Takahashi, Chem. - Eur. J., 2015, 21, 9742; $(f)$ K. D. Seo, I. T. Choi and H. K. Kim, Chem. - Eur. J., 2015, 21, 14804; ( $g$ ) B. Liu, F. Giordano, K. Pei, J.-D. Decoppet, W.-H. Zhu, S. M. Zakeeruddin and M. Grätzel, Chem. - Eur. J., 2015, 21, 18654; (h) Z. Yao, M. Zhang, R. Li, L. Yang, Y. Qiao and P. Wang, Angew. Chem., Int. Ed., 2015, 54, 5994; (i) P. Brogdon, F. Giordano, G. A. Puneky, A. Dass, S. M. Zakeeruddin, M. K. Nazeeruddin, M. Grätzel, G. S. Tschumper and J. H. Delcamp, Chem. - Eur. J., 2016, 22, 694; ( $j$ ) S. Irie, S. Fuse, M. M. Maitani, Y. Wada, Y. Ogomi, S. Hayase, T. Kaiho, H. Masui, H. Tanaka and T. Takahashi, Chem. - Eur. J., 2016, 22, 2507; (k) F.-L. Guo, Z.-Q. Li, X.-P. Liu, L. Zhou, F.-T. Kong, W.-C. Chen and S.-Y. Dai, Adv. Funct. Mater., 2016, 26, 5733.

18 (a) Y. Ooyama, S. Inoue, R. Asada, G. Ito, K. Kushimoto, K. Komaguchi, I. Imae and Y. Harima, Eur. J. Org. Chem., 2010, 92; (b) Y. Ooyama, S. Inoue, T. Nagano, K. Kushimoto, J. Ohshita, I. Imae, K. Komaguchi and Y. Harima, Angew. Chem., Int. Ed., 2011, 50, 7429; (c) Y. Ooyama, T. Nagano, S. Inoue, I. Imae, K. Komaguchi, J. Ohshita and Y. Harima, Chem. - Eur. J., 2011, 17, 14837; (d) Y. Ooyama, N. Yamaguchi, I. Imae, K. Komaguchi, J. Ohshita and Y. Harima, Chem. Commun., 2013, 49, 2548; (e) Y. Ooyama, Y. Hagiwara, T. Mizumo, Y. Harima and J. Ohshita, New J. Chem., 2013, 37, 2479; $(f)$ Y. Ooyama, T. Sato, Y. Harima and J. Ohshita, J. Mater. Chem. A, 2014, 2, 3293; (g) Y. Ooyama, K. Uenaka and J. Ohshita, Eur. J. Org. Chem., 2015, 3713; (h) Y. Ooyama, K. Uenaka, T. Kamimura, S. Ozako, M. Kanda, T. Koide and F. Tani, RSC Adv., 2016, 6, 16150.

19 (a) Y. Harima, T. Fujita, Y. Kano, I. Imae, K. Komaguchi, Y. Ooyama and J. Ohshita, J. Phys. Chem. C, 2013, 117, 16364; (b) N. Shibayama, H. Ozawa, M. Abe, Y. Ooyama and H. Arakawa, Chem. Commun., 2014, 50, 6398; (c) Y. Ooyama, K. Uenaka, T. Sato, N. Shibayama and J. Ohshita, RSC Adv., 2015, 5, 2531; (d) J. Ohshita, Y. Adachi, D. Tanaka, M. Nakashima and Y. Ooyama, RSC Adv., 2015, 5, 36673; (e) Y. Harima, Y. Kano, T. Fujita, I. Imae, Y. Ooyama and J. Ohshita, $R S C A d v$., 2015, 5, 71387; $(f)$ Y. Adachi, Y. Ooyama, N. Shibayama and J. Ohshita, Dalton Trans., 2016, 45, 13817.

20 (a) D. Daphnomili, G. D. Sharma, S. Biswas, T. K. R. Justin and A. G. Goutsolelos, J. Photochem. Photobiol., A, 2013, 253, 88; (b) J. Lu, X. Xu, Z. Li, K. Cao, J. Cui, Y. Zhang, Y. Shen, Y. Li, J. Zhu, S. Dai, W. Chjen, Y. Cheng and M. Wang, Chem. - Asian J., 2013, 8, 956; (c) M.-D. Zhang, H.-X. Xie, X.-H. Ju, L. Qin, Q.-X. Yang, H.-G. Zheng and 
X.-F. Zhou, Phys. Chem. Chem. Phys., 2013, 15, 634-661; (d) D. Daphnomili, G. Landrou, P. Singh, A. Thomas, K. Yesudas, B. K. G. D. Sharma and A. G. Goutsolelos, RSC $A d v$., 2012, 2, 12899; (e) L. Wang, X. Yang, S. Li, M. Cheng and L. Sun, RSC Adv., 2013, 3, 13677; $(f)$ T. Sakurada, Y. Arai and H. Segawa, RSC Adv., 2014, 4, 13201; $(g)$ J. Mao, D. Wang, S.-H. Liu, Y. Hang, Y. Xu, Q. Zhang, W. Wu, P.-T. Chou and J. Hua, Asian J. Org. Chem., 2014, 3, 153; (h) T. Ikeuchi, S. Agrawal, M. Ezoe, S. Mori and M. Kimura, Chem. - Asian J., 2015, 10, 2347.

21 (a) C. Stangel, A. Bagaki, P. A. Angaridis, G. Charalambidis, G. D. Sharma and A. G. Coutsolelos, Inorg. Chem., 2014, 53, 11871; (b) M. N. K. P. Bolisetty, C.-T. Li, K. R. J. Thomas, G. B. Bodedla and K.-C. Ho, Tetrahedron, 2014, 70, 4203; (c) D. Franchi, M. Calamante, G. Reginato, L. Zani, M. Peruzzini, M. Taddei, F. F. de Biani, R. Basosi, A. Sinicropi, D. Colonna, A. Di Carlo and A. Mordin, Tetrahedron, 2014, 70, 6285; (d) E. V. Verbitskiy, E. M. Cheprakova, J. O. Subbotina, A. V. Schepochkin, P. A. Slepukhin, G. L. Rusinov, V. N. Charushin, O. N. Chupakhin, N. I. Makarova, A. V. Metelitsa and V. I. Minkin, Dyes Pigm., 2014, 100, 201; (e) C.-L. Mai, T. Moehl, C.-H. Hsieh, J.-D. Décoppet, S. M. Zakeeruddin, M. Grätzel and C.-Y. Yeh, ACS Appl. Mater. Interfaces, 2015, 7, 14975; $(f)$ H. Jia, K. Shen, X. I. Ju, M. Zhanga and H. Zheng, New J. Chem., 2016, 40, 2799; (g) P. A. Angaridis, E. Ferentinos, G. Charalambidis, K. Ladomenou, V. Nikolaou, S. Biswas, G. D. Sharma and A. G. Coutsolelos, RSC Adv., 2016, 6, 22187; (h) U. Meinhardt, F. Lodermeyer, T. A. Schaub, A. Kunzmann, P. O. Dral, A. C. Sale, F. Hampel, D. M. Guldi, R. D. Costa and M. Kivala, RSC Adv., 2016, 6, 67372 .

22 (a) H. Frei, D. J. Fitzmaurice and M. Grätzel, Langmuir, 1990, 6, 198; (b) J. Moser, S. Punchihewa, P. P. Infelta and M. Grätzel, Langmuir, 1991, 7, 3012; (c) N. J. Cherepy, G. P. Smestad, M. Grätzel and J. Z. Zhang, J. Phys. Chem. B, 1997, 101, 9342; (d) R. Huber, S. Spcrlein, J. E. Moser, M. Grätzel and J. Wachtveitl, J. Phys. Chem. B, 2000, 104, 8995; (e) P. Persson, R. Bergström and S. Lunell, J. Phys. Chem. B, 2000, 104, 10348; $(f)$ E. Hao, N. A. Anderson, J. B. Asbury and T. Lianl, J. Phys. Chem. B, 2002, 106, 10191; (g) Y. Wang, K. Hang, N. A. Anderson and T. Lian, J. Phys. Chem. B, 2003, 107, 9434.

23 (a) S.-C. Li, J.-G. Wang, P. Jacobson, X.-Q. Gong, A. Selloni and U. Dieboldi, J. Am. Chem. Soc., 2009, 131, 980; (b) L.-M. Liu, S.-C. Li, H. Cheng, U. Diebold and A. Selloni, J. Am. Chem. Soc., 2011, 133, 7816; (c) S. A. Agarkar, R. R. Kulkarni, V. V. Dhas, A. A. Chinchansure, P. Hazra, S. P. Joshi and S. B. Ogale, ACS Appl. Mater. Interfaces, 2011, 3, 2440; (d) S. Li, X. Yang, D. Qu, W. Wang, Y. Wang and L. Sun, Chin. J. Chem., 2012, 30, 2315.

24 (a) R. Sánchez-de-Armas, J. O. López, M. A. San-Miguel and J. F. Sanz, J. Chem. Theory Comput., 2010, 6, 2856; (b) R. Sánchez-de-Armas, J. Oviedo, M. A. San-Miguel and J. F. Sanz, J. Phys. Chem. C, 2011, 115, 11293; (c) R. Sánchezde-Armas, M. A. San-Miguel, J. Oviedo, A. Márquez and J. F. Sanz, Phys. Chem. Chem. Phys., 2011, 13, 1506; (d) R. Sánchez-de-Armas, M. A. San-Miguel, J. Oviedo and J. F. Sanz, Comput. Theor. Chem., 2011, 975, 99.

25 (a) L. G. C. Rego and V. S. Batista, J. Am. Chem. Soc., 2003, 125, 7989; (b) S. G. Abusabara, L. G. C. Rego and V. S. Batista, J. Am. Chem. Soc., 2005, 127, 18234; (c) S. G. Abuabara, G. W. Cady, J. B. Baxter, C. A. Schmuttenmaer, R. H. Crabtree, G. W. Brudvig and V. S. Batsista, J. Phys. Chem. C, 2007, 111, 11982; (d) L. G. C. Rego, R. de Silva, J. A. Freire, R. C. Snoeberger and V. S. Batsista, J. Phys. Chem. $C$, 2010, 114, 1317; (e) W. Macyk, K. Szaciłowski, G. Stochel, M. Buchalska, J. Kuncewicz and P. Łabuz, Coord. Chem. Rev., 2010, 254, 2687; $(f)$ H. J. Nam, B. Kim, M. J. Ko, M. Jin, J. M. Kim and D.-Y. Jung, Chem. - Eur. J., 2012, 18, 14000.

26 (a) W. R. Duncan, W. M. Stier and O. V. Prezhdo, J. Am. Chem. Soc., 2005, 127, 7941; (b) T. Lana-Villarreal, A. Rodes, J. M. Pérez and R. Gómez, J. Am. Chem. Soc., 2005, 127, 12601; (c) W. R. Duncan, W. M. Stier and O. V. Prezhdo, J. Phys. Chem. B, 2005, 109, 365; (d) W. R. Duncan, C. F. Craig and O. V. Prezhdo, J. Am. Chem. Soc., 2007, 129, 8528; (e) S. Verma, P. Kar, A. Das, D. K. Palit and H. N. Ghosh, Chem. - Eur. J., 2010, 16, 611; $(f)$ S. Verma, P. Kar, A. Das and H. N. Ghosh, Chem. - Eur. J., 2011, 17, 1561.

27 (a) E. L. Tae, S. H. Lee, J. K. Lee, S. S. Yoo, E. J. Kang and K. B. Yoon, J. Phys. Chem. B, 2005, 109, 22513; (b) B.-K. An, W. Hu, P. L. Burn and P. Meredith, J. Phys. Chem. C, 2010, 114, 17964; (c) M. Adineh, P. Tahay, M. Ameri, N. Safari and E. Mohajerani, $R S C A d v ., 2016,6,14512$.

28 I. A. Janković, Z. V. Šaponjic, M. I. Čomor and J. M. Nedeljković, J. Phys. Chem. C, 2009, 113, 12645.

29 (a) Y. Ooyama, T. Yamada, T. Fujita, Y. Harima and J. Ohshita, J. Mater. Chem. A, 2014, 2, 8500; (b) Y. Ooyama, M. Kanda, K. Uenaka and J. Ohshita, ChemPhysChem, 2015, 16, 3049.

30 (a) S. Manzhos and K. Kotsis, Chem. Phys. Lett., 2016, 660, 69;

(b) J. Fujiwara and M. Nagata, Chem. Phys. Lett., 2015, 619, 180; (c) G. Ramakrishna, D. A. Jose, D. K. Kumar, A. Das, D. K. Palit and H. N. Ghosh, J. Phys. Chem. B, 2005, 109, 15445; (d) F. de Angelis, Chem. Phys. Lett., 2010, 493, 323; (e) S. Namuangruk, R. Fukuda, M. Ehara, J. Meeprasert, T. Khanasa, S. Morada, T. Kaewin, S. Jungsuttiwong, T. Sudyoadsuk and V. Promarak, J. Phys. Chem. C, 2012, 116, 25653.

31 Q. Zeng, Z. Li, Y. Dong, C. Di, A. Qin, Y. Hong, Z. Zhu, C. K. W. Jim, G. Yu, Q. Li, Z. Li, Y. Liu, J. Qin and B. Z. Tang, Chem. Commun., 2007, 70.

32 D. Gudeika, J. V. Grazulevicius, D. Volyniuk, R. Butkute, G. Juska, A. Misaojedovas, A. Gruodis and S. Jursenas, Dyes Pigm., 2015, 114, 239.

33 M. J. Frisch, G. W. Trucks, H. B. Schlegel, G. E. Scuseria, M. A. Robb, J. R. Cheeseman, G. Scalmani, V. Barone, B. Mennucci, G. A. Petersson, H. Nakatsuji, M. Caricato, X. Li, H. P. Hratchian, A. F. Izmaylov, J. Bloino, G. Zheng, J. L. Sonnenberg, M. Hada, M. Ehara, K. Toyota, R. Fukuda, J. Hasegawa, M. Ishida, T. Nakajima, Y. Honda, O. Kitao, H. Nakai, T. Vreven, J. A. Montgomery, Jr., J. E. Peralta, F. Ogliaro, M. Bearpark, J. J. Heyd, E. Brothers, K. N. Kudin, 
V. N. Staroverov, R. Kobayashi, J. Normand, K. Raghavachari, A. Rendell, J. C. Burant, S. S. Iyengar, J. Tomasi, M. Cossi, N. Rega, J. M. Millam, M. Klene, J. E. Knox, J. B. Cross, V. Bakken, C. Adamo, J. Jaramillo, R. Gomperts, R. E. Stratmann, O. Yazyev, A. J. Austin, R. Cammi, C. Pomelli, J. W. Ochterski, R. L. Martin, K. Morokuma, V. G. Zakrzewski, G. A. Voth, P. Salvador, J. J. Dannenberg, S. Dapprich, A. D. Daniels, O. Farkas, J. B. Foresman, J. V. Ortiz,
J. Cioslowski and D. J. Fox, Both the geometry optimization and energy calculation were performed by employing the density functional theory (DFT), at the level of B3LYP/6-31G(d, p) on the Gaussian09 program package (Gaussian 09, Revision A.02), Gaussian, Inc., Wallingford CT, 2009.

34 J. Li, B. Zhang, H. Yuan, X. Xu, K. Cao, J. Cui, S. Liu, Y. Shen, Y. Cheng, J. Xu and M. Wang, J. Phys. Chem. C, 2014, 118, 14739. 